\title{
Pedological Characterization and Suitability Assessment for Cassava Production in Bukoba, Missenyi and Biharamulo Districts, Tanzania
}

\author{
Mgeta Steven Merumba ${ }^{1,2, ~ *, ~ B a l t h a z a r ~ M i c h a e l ~ M s a n y a ~}{ }^{1}$, Ernest Semu ${ }^{1}$, \\ Johnson Mashambo Semoka ${ }^{1}$ \\ ${ }^{1}$ Department of Soil and Geological Sciences, Sokoine University of Agriculture, Morogoro, Tanzania \\ ${ }^{2}$ Maruku Research Centre, Tanzania Agricultural Research Institute (TARI), Bukoba, Tanzania \\ Email address: \\ smerumbason@gmail.com (M. S. Merumba),bmmsanya@gmail.com (B. M. Msanya), semu@suanet.ac.tz(E. Semu), \\ semoka@yahoo.com (J. M. Semoka) \\ ${ }^{*}$ Corresponding author
}

\section{To cite this article:}

Mgeta Steven Merumba, Balthazar Michael Msanya, Ernest Semu, Johnson Mashambo Semoka. Pedological Characterization and Suitability Assessment for Cassava Production in Bukoba, Missenyi and Biharamulo Districts, Tanzania. American Journal of Agriculture and Forestry. Vol. 8, No. 4, 2020, pp. 144-166. doi: 10.11648/j.ajaf.20200804.18

Received: June 30, 2020; Accepted: July 13, 2020; Published: July 28, 2020

\begin{abstract}
A study was conducted in Bukoba, Missenyi and Biharamulo Districts, Tanzania with the objectives of characterizing, classifying and assessing the suitability of the study area for cassava production. A reconnaissance field survey using transect walks and auger observations was done in the study sites, which were geo-referenced in terms of international coordinates using Global Positioning System. Soil profiles representative of the study sites were excavated and named as MARU-P1, MISSE-P1 and BIHA-P1 for Bukoba, Missenyi and Biharamulo Districts, respectively. Soil profile description and data on the morphological features of the representative soils were collected according to the FAO Guidelines for Soil Description. Disturbed and undisturbed soil samples were collected from genetic soil horizons, processed and analyzed in a soil laboratory. Data on site characteristics, climate, soil morphological features and soil physical and chemical properties were used to classify the soils to the family level of the USDA Soil Taxonomy and to tier-2 of the FAO World Reference Base for Soil Resources. Soil suitability assessment of the experimental sites was done using a simple limitation method based on the FAO Framework for Land Evaluation. The results reveal that Pedons MARU-P1 and BIHA-P1 have similar morphological properties, which are different from pedon MISSE-P1. However, the studied pedons differ in their physical and chemical properties, implying differences in their use and management. The climate of the study sites is semi-humid with Udic soil moisture regime, which is generally favourable for crop production. According to the USDA Soil Taxonomy, pedons MARUP1 and BIHA-P1 were classified as "Typic Kandiudults". In addition, according to FAO World Reference Base for Soil Resources, pedons MARU-P1 and BIHA-P1 were classified as "Haplic Ferralic Acrisols" and "Chromic Ferralic Acrisols", respectively. Pedon MISSE-P1 was classified as "Typic Endoaquolls" according to USDA Soil Taxonomy and as "Fluvic Gleyic Phaeozems" according to FAO World Reference Base for Soil Resources. Pedons MISSE-P1 and BIHA-P1 were both evaluated as marginally suitable while MARU-P1 pedon was evaluated as moderately suitable for cassava production due to soil fertility constraints. We recommended specific soil fertility management strategies in each studied site for optimum cassava yields.
\end{abstract}

Keywords: Pedological Characterization, Soil Characterization, Suitability Assessment, Cassava Production, Physical and Chemical Properties, Soil Fertility Management 


\section{Introduction}

Interpretation towards land use potential for specific land use types is very important before making decisions on land uses. This is achieved through gathering soil information by systematic identification, grouping and delineation of the soils [1]. The intensification of agriculture requires a clear knowledge of the soil as a resource and attributes of the land together with understanding the potentials and constraints of the land for soil and water management [1]. Nevertheless, acquisition of this information is a challenge due to the limited knowledge on crop nutrient requirements, characteristics of soils and high level of variation in soil properties [2]. Improvement on crop productivity is greatly dependent on efficient utilization and management of soils [3]. Good database on soil properties and related site characteristics is of great importance in advising land users on how to use the land in the best possible way [1]. Variability of soils is the result of natural processes and management practices. Natural variability results from geological and pedological processes [4]. Soil forming factors namely climate, parent materials, living organisms, relief and time influence the morphological, physical, chemical and biological characteristics of soils $[5,6,7]$. Pedological characterization is a systematic way of collecting soil information for understanding soils in terms of their morphological, physical, chemical, biological and mineralogical properties leading to clear understanding of the potentials and limitations of the soils for crop production in a particular area $[8,9]$. Moreover, pedological characterization is a major building block for understanding the soil, classifying it and getting the best understanding of the environment $[10,11]$.

Soil characterization and classification help to organize knowledge and facilitate the transfer of experience and technology from one place to another $[12,13]$. Also they provide valuable information and understanding of the physical, chemical, mineralogical and biological properties of the soils for assessing soil fertility [14] to untie some unique soil problems and establish appropriate soil management strategies $[15,11]$. This helps in the selection of the best agricultural enterprises for a particular soil [16] for improving crop production and soil and water management [1]. Soil characterization also provides insight on the suitability of soil for production of specific crops because climatic and soil-site parameters play significant role in crop performance and yields [17].

Soil suitability evaluation involves characterizing, assessing and grouping the soils in a given area in terms of their suitability for specific land use type [18] as a function of crop requirements and soil characteristics. Therefore, matching the soil qualities (nutrients availability and retention, toxicity, soil reaction, drainage, water availability), terrain and climate with the crop requirements provides soil suitability $[19,20]$. Soil suitability classification is useful because some land attributes (soil, climate and topography) can be suitable for specific crops but unsuitable for others [21]. Therefore, soil suitability is a measure of how well the qualities of a soil match the crop requirements [7].

Conducting a meaningful fertilizer trial at a particular site requires the characterization of the soils of the respective site to enable transfer of soil information from one place to another [1, 16, 22]. In Tanzania, appreciable initiatives on collecting basic information on soil characterization, classification and soil suitability assessment in different locations through soil survey have been done [23, 24, 5, 1, $25,26,8,6,11,22,7,9,27]$. However, the available information remains rather scanty relative to the large size of the country and its diverse soils and other land resources [1, 22]. Like in most parts of Tanzania, limited information is available on pedological characterization, classification and suitability assessment of the soils of Bukoba Rural, Missenyi and Biharamulo Districts for crop production. It is for this reason that this study was conducted with the objectives of characterizing the soils in terms of their morphological, physical, chemical and mineralogical characteristics; and classifying the soils to family level of the United States Department of Agriculture (USDA) Soil Taxonomy and to Tier-2 of the World Reference Base (WRB) for Soil Resources and assessing the suitability of the soils of the study area for cassava production.

\section{Materials and Methods}

\subsection{Description of the Study Area}

\subsubsection{Location of the Study Area}

Kagera region is located in the north-western corner of Tanzania on the western shore of Lake Victoria (Figure 1) between latitudes $1^{\circ} 00^{\prime}$ and $3^{\circ} 45^{\prime}$ south of Equator and between longitudes $30^{\circ} 25^{\prime}$ and $32^{\circ} 40^{\prime}$ east of Greenwich. It is the fifteenth largest region in Tanzania with an area of about $3,568,600$ ha of land, which accounts for approximately $3.3 \%$ of Tanzania's total land area. Out of the region's area, 10,173 ha are covered by water of the Lake Victoria, Ikimba and Burigi, and the Ngono and Kagera rivers [28]. Administratively, the region has seven districts, namely Biharamulo, Bukoba, Karagwe, Kyerwa, Missenyi, Muleba and Ngara, and borders four countries, namely Uganda, Rwanda, Burundi, and Kenya across Lake Victoria (Figure 1). This study was conducted in three districts, namely Bukoba, Missenyi and Biharamulo. The representative study sites were Tanzania Agricultural Research Institute (TARI), Maruku centre in Butairuka village, Bukoba District; Mabuye Primary School in Mabuye village, Missenyi District; and Rukaragata Farmers' Extension Centre in Rukaragata village, Biharamulo District. Bukoba District covers an area of 284,100 ha and is situated between latitudes $1^{\circ} 00^{\prime}$ and $3^{\circ} 00^{\prime} \mathrm{S}$ and between longitudes $30^{\circ} 45^{\prime}$ and $31^{\circ} 00^{\prime} \mathrm{E}$ with altitude between 1200 1400 meters above sea level. Missenyi District covers an area of 270,875 ha and is situated between latitudes $1^{\circ} 00^{\prime}$ and $1^{\circ}$ $30^{\prime} \mathrm{S}$ and between longitudes $30^{\circ} 48^{\prime}$ and $31^{\circ} 49^{\prime} \mathrm{E}$ with attitude between 1100 - 1400 meters above sea level. 
Biharamulo District covers an area of 374,400 ha and is situated between latitudes $2^{\circ} 15^{\prime}$ and $3^{\circ} 15^{\prime} \mathrm{S}$ and between longitudes $31^{\circ} 00^{\prime}$ and $32^{\circ} 00^{\prime} \mathrm{E}$ with altitude ranging from 1100 - 1700 meters above sea level [28]. Based on rainfall three agro-ecological zones, namely high (Bukoba), medium (Missenyi), and low (Biharamulo) rainfall zones are found in Kagera Region [29, 30].

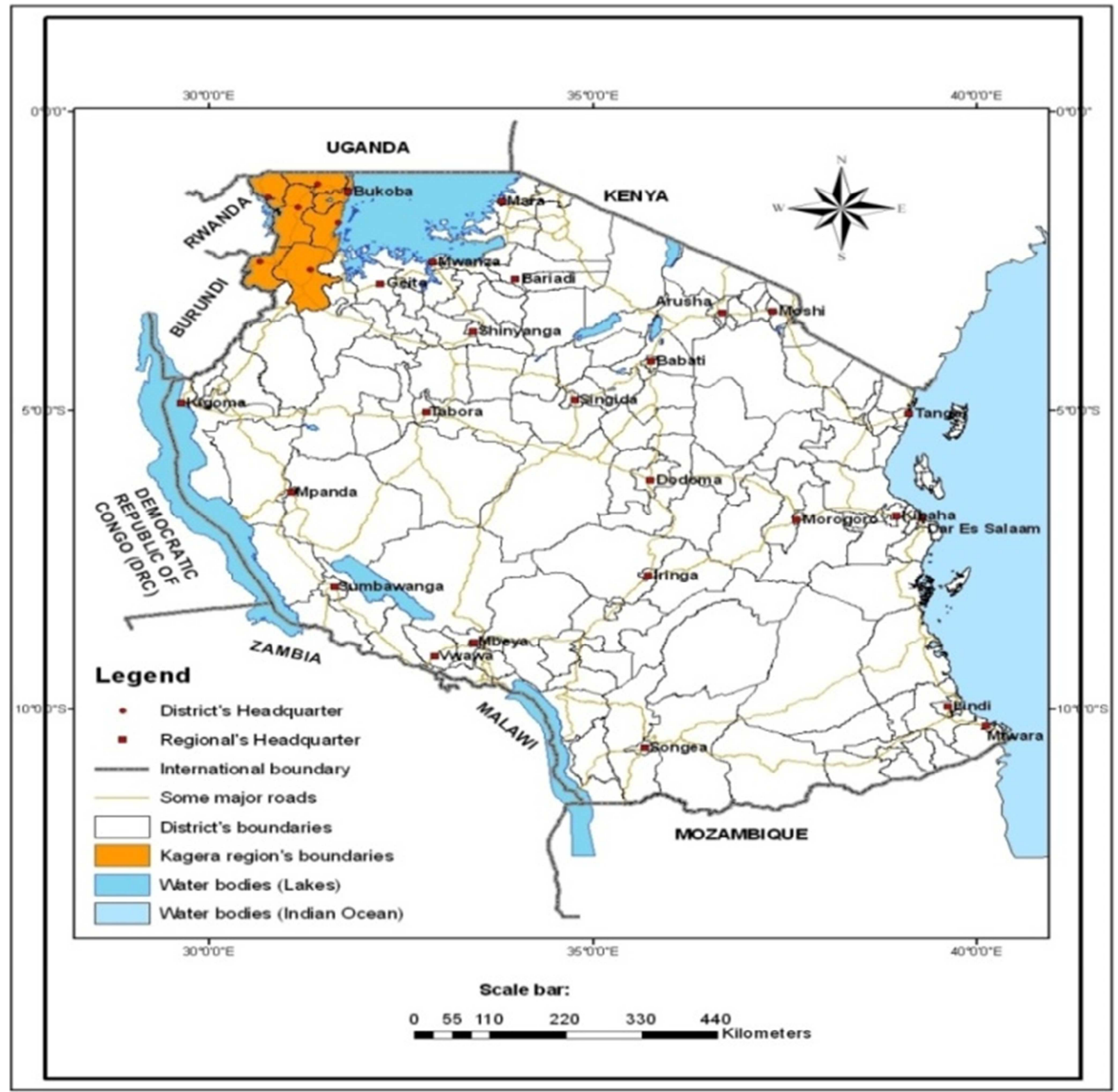

Figure 1. Location of Kagera Region and its Districts in Tanzania.

\subsubsection{Climate and Soils of the Study Area}

The districts in Kagera Region experience bimodal rainfall distribution between September and December (short rains) and between March and June (long rains). The mean annual rainfall ranges from $900-2400 \mathrm{~mm}$ in Bukoba District, 600$2000 \mathrm{~mm}$ in Missenyi District and $700-1000 \mathrm{~mm}$ in Biharamulo District [29, 31]. The mean annual temperature ranges from $16-28^{\circ} \mathrm{C}$, Missenyi having higher annual temperature $\left(28^{\circ} \mathrm{C}\right)$ than Bukoba and Biharamulo $\left(26^{\circ} \mathrm{C}\right)$. In terms of soil texture, the soils range from sandy clay loam to sandy clay and clay [29].

\subsection{Field Work}

\subsubsection{Reconnaissance Field Survey}

Reconnaissance field survey using transect walks and auger observations was done in all study sites to understand the heterogeneity of the soils. At each observation point, site data on landform, soil morphological features (soil 
colour, texture, consistence, structure, porosity, and effective depth), parent material, natural vegetation, drainage, slope gradient, elevation, erosion and land use were recorded and filled in forms designed by the National Soil Service, Tanzania, adopted from the FAO Guidelines for Soil Description [32]. Soil colour was determined using Munsell colour charts [33]. This helped to select the representative study sites for laying out the experimental trials, soil sampling and excavation of the soil profile pits. The representative study sites (Figure 2) were located by international coordinates using Global Positioning System (GPS) (model GARMIN etrex 20).

\subsubsection{Soil Profile Excavation}

After conducting reconnaissance field survey in each study site, the point within each study site for soil profile excavation was identified and geo-referenced (Figure 2), by international coordinates using Global Positioning System (GPS). In each representative study site, one soil profile pit of $150 \mathrm{~cm}$ width, $200 \mathrm{~cm}$ length and depth ranging from $167-$ $200 \mathrm{~cm}$ was excavated. The profiles were named as MARUP1, MISSE-P1 and BIHA-P1 for TARI-Maruku site, Mabuye Primary School site and Rukaragata Extension Centre site respectively for Bukoba, Missenyi and Biharamulo Districts (Figure 3).

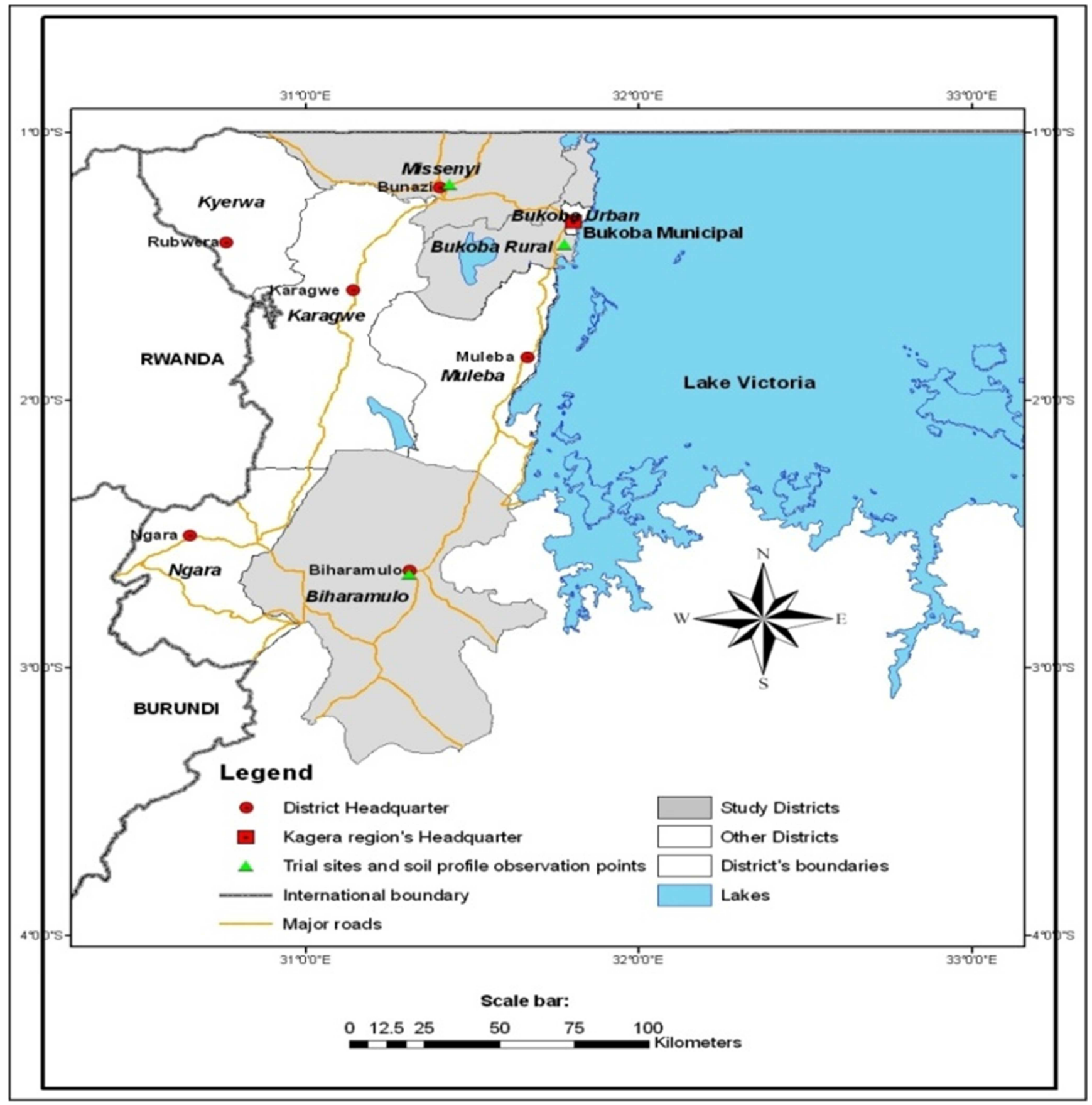

Figure 2. Location of trial sites and soil profile observation points in the study sites. 


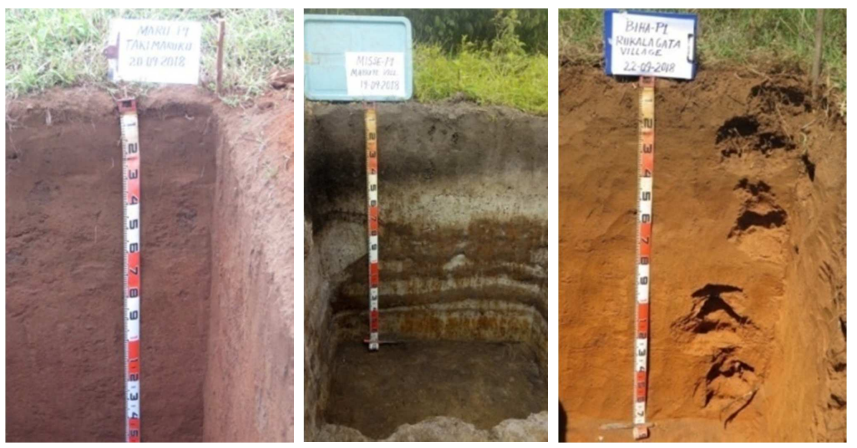

Figure 3. Soil profiles excavated at Maruku (MARU-P1), Mabuye (MISSEP1) and Rukaragata (BIHA-P1) villages in Bukoba, Missenyi and Biharamulo Districts, respectively.

The genetic soil horizons in each soil profile pit were demarcated followed by collection of disturbed soil samples from each soil horizon and undisturbed soil samples (core samples) from three soil horizons at $0-35,35-105$ and 115 - $200 \mathrm{~cm}$ depths, packed and well labeled for laboratory analysis. Soil colours were determined using Munsell colour charts [33]. Soil penetration resistance was measured in each soil horizon using pocket cone penetrometer (Daiki RikaKogyo penetrometer Model DIK-5551) [34]. Ten different points (10 values) were taken within the respective horizon and averaged to get one mean penetration resistance value per horizon that was compared to the critical value of 3 $\mathrm{MPa}$ adopted as a critical value for plant growth $[35,34,36$, 37, 38]. Disturbed soil samples were air-dried, ground and sieved through $2 \mathrm{~mm}$ sieve, packed in paper bags and well labeled for physical and chemical soil properties determination in the soil laboratory.

\subsection{Laboratory Analysis of Soil Samples}

Soil samples for determining bulk density, porosity and moisture retention characteristics were analyzed at Tanzania Agricultural Research Institute (TARI), Mlingano Soil Laboratory in Muheza District, Tanzania. Soil samples for determining total elemental composition were analyzed at the Geological Survey of Tanzania (GST) Laboratory in Dodoma city, Tanzania. Soil samples for determining other soil physical and chemical properties were analyzed at Sokoine University of Agriculture (SUA) Soil Science Laboratory in Morogoro, Tanzania.

Particle size distribution was determined by hydrometer method [39, 40] after dispersing the soils with sodium hexametaphosphate. Soil textural classes were determined using the USDA textural triangle [41]. Bulk density (BD) was determined gravimetrically by drying undisturbed core soil samples at $105^{\circ} \mathrm{C}$ for 24 hours, and then calculating soil BD after weighing the dried core soil samples and empty cores [42, 43]. Soil moisture retention characteristics were determined using sand-kaolin box for low suction values and pressure plate membrane apparatus for high suction values [44, 42].

Soil $\mathrm{pH}$ in water and in $1 \mathrm{M} \mathrm{KCl}$ and electric conductivity (EC) were measured potentiometrically [40, 45] using a soil:water, soil: $\mathrm{KCl}$ and soil:water ratio of $1: 2.5$, respectively, weight to volume basis using a soil $\mathrm{pH}$-meter for soil $\mathrm{pH}$ and EC-meter for eclectic conductivity. Organic carbon (OC) was determined by the Walkey-Black wet oxidation method [46] and its value converted to organic matter (OM) by multiplying with a factor of 1.724 [47]. Total nitrogen (TN) was determined by micro-Kjeldahl digestion method [48], extractable phosphorus (P) by Bray and Kurtz-1 method [49]. Cation exchange capacity (CEC) of the soil and exchangeable bases $\left(\mathrm{Ca}^{2+}, \mathrm{Mg}^{2+}, \mathrm{K}^{+}\right.$and $\left.\mathrm{Na}^{+}\right)$extracted by ammonium acetate $\left(\mathrm{NH}_{4} \mathrm{OAc}\right)-\mathrm{pH} 7$ saturation method [50] were determined using atomic absorption spectrophotometer [51] for $\mathrm{Ca}^{2+}$ and $\mathrm{Mg}^{2+}$ and flame photometer for $\mathrm{K}^{+}$and $\mathrm{Na}^{+}$ [40]. The absorbed $\mathrm{NH}_{4}{ }^{+}$was displaced by $\mathrm{K}^{+}$using $1 \mathrm{M} \mathrm{KCl}$ followed by determination of CEC by Kjeldahl distillation method. The $\mathrm{CEC}_{\text {clay }}$ was calculated by dividing $\mathrm{CEC}_{\text {soil }}$ by percentage clay and multiplying by 100 . Micronutrients $(\mathrm{Cu}$, $\mathrm{Fe}, \mathrm{Zn}, \mathrm{Mn}$ ) extracted by diethylenetriaminepentaacetic acid (DTPA) method [52, 50] were determined using atomic absorption spectrophotometer [51]. The total exchangeable bases (TEB) were calculated as the sum of the four exchangeable bases $\left(\mathrm{Ca}^{2+}, \mathrm{Mg}^{2+}, \mathrm{K}^{+}\right.$and $\left.\mathrm{Na}^{+}\right)$for a given soil sample. The $\mathrm{C}: \mathrm{N}$ ratio, silty:clay ratio, exchangeable sodium percentage (ESP) and base saturation percentage (BS\%) were calculated using formulas by [53]. Chemical index of alteration (CIA) was calculated as: $\mathrm{CIA}=\left[\mathrm{Al}_{2} \mathrm{O}_{3} /\left(\mathrm{Al}_{2} \mathrm{O}_{3}+\right.\right.$ $\left.\left.\mathrm{K}_{2} \mathrm{O}+\mathrm{Na}_{2} \mathrm{O}+\mathrm{CaO}\right) * 100\right]$.

Total elemental composition of soil samples was determined using X-Ray Fluorescence Spectrometry (XRF) method whereby, $200 \mathrm{~g}$ of fine earth soil samples were weighed and open air-dried by using Infrared lamps for two hours. Samples were then ground to particle size $\leq 177 \mu \mathrm{m}$ (75 Mesh) using swing mill pulverizer. The pressed powder without binder technique was used to prepare pellets for XRF analysis [54] and quantification of oxides of $\mathrm{Mg}$ and $\mathrm{Na}$ was done using an AAS machine version 208FS. Other elemental oxides were measured using PANalytical, Minipal 4 Energy Dispersive X-Ray Fluorescence Spectrometer (ED-XRF) Model PW4030/45B [55]. Weathering potential of the studied pedons was assessed based on the silica/aluminum oxide ratio, silica/sesquioxide ratio and CIA.

\subsection{Soil Classification}

The collected field data (site characteristics, climate and soil morphological features) and data obtained after laboratory analysis (physical and chemical properties of the soils) were used to classify the soils to family level of the USDA Soil Taxonomy [41] and to tier-2 of the FAO World Reference Base for Soil Resources [56].

\subsection{Soil Suitability Assessment}

The suitability of a given piece of land is its natural ability to support a specific purpose. Soil suitability assessment involves characterization of the soils in a given area for specific land use type based on knowledge of crop requirements, prevailing soil conditions and soil management [18]. Crop requirements are understood within the context of 
limitations imposed by soil and other features, which do not form part of the soil but may have a significant influence on use of the soil $[57,18]$. Therefore, soil suitability quantifies the extent soil conditions match crop requirements under defined input and management circumstances [18]. The soil suitability classification consists of assessing and grouping the pedons into four categories, namely orders, classes, subclasses and units based on the crop requirements $[57,58$, 18]. The orders reflect kind of suitability, which include suitable (S) and not suitable (N). The classes reflect degree of suitability within the order, which include highly suitable (S1), moderately suitable (S2) and marginally suitable (S3), currently not suitable (N1) and permanently not suitable (N2). Subclasses reflect kind of limitations or main kind of improvement measures required within the classes $(\mathrm{S} 2 \mathrm{n}$ nutrient availability is a limitation or S3me - moisture availability and erosion are the limitations) and units reflect minor differences in required management within the subclasses (S2e-1 or S2e-2) [57]. In this study, suitability assessment of the experimental sites for cassava production was done using the simple limitation method [57, 58]. The observed land characteristics including rainfall, temperature, slope, drainage, soil texture, effective soil depth and soil nutrient content were compared with the ecological requirement of cassava crop $[59,60,61]$ for suggesting the suitability of the studied pedons. Howeler [59] stated the following chemical soil characteristics as the nutritional requirement of cassava crop: $\mathrm{pH}(4.5-7.0)$, organic carbon $\left(20-40 \mathrm{~g} \mathrm{~kg}^{-1}\right)$ equivalent to $(0.2-0.4 \%)$, total nitrogen $(1.5$ - $\left.2.0 \mathrm{~g} \mathrm{~kg}^{-1}\right)$ equivalent to $(0.14-0.20 \%)$, phosphorus (10 to $\left.14 \mathrm{mg} \mathrm{kg}^{-1}\right)$, potassium $\left(0.2-0.4 \mathrm{cmol}(+) \mathrm{kg}^{-1}\right)$, calcium $(1.0$ - $\left.5.0 \mathrm{cmol}(+) \mathrm{kg}^{-1}\right)$, Magnesium $\left(0.4-1.0 \mathrm{cmol}(+) \mathrm{kg}^{-1}\right)$, electrical conductivity $\left(2-4 \mathrm{dS} \mathrm{m}^{-1}\right)$, Na saturation (ESP) $<$ $6 \%$, copper $\left(0.30-1.0 \mathrm{mg} \mathrm{kg}^{-1}\right)$, manganese $(10.0-100.0 \mathrm{mg}$ $\left.\mathrm{kg}^{-1}\right)$, iron (10.0 - $\left.100.0 \mathrm{mg} \mathrm{kg}^{-1}\right)$ and zinc $\left(1.0-5.0 \mathrm{mg} \mathrm{kg}^{-1}\right)$. In addition, Cock (1985) and Howeler (2011) reported that cassava can grow well in the area with slope from $0-15 \%$, rainfall from $50-3000 \mathrm{~mm}$, temperature from $18-30^{\circ} \mathrm{C}$, moderately deep $(>50-100 \mathrm{~cm})$ to very deep $(>150 \mathrm{~cm})$ soil, moderate to well drained soil and soil texture of sandy loam, sandy clay loam and other loam soils.

\section{Results and Discussion}

\subsection{Characteristics of the Representative Study Sites in Bukoba, Missenyi and Biharamulo Districts}

The representative study sites were characterized based on agro-ecological zone, location (coordinates), altitude, landform, geology, slope, land use, natural vegetation, natural drainage, flooding, soil moisture regime (SMR), soil temperature regime (STR) and mean annual rainfall (Table 1). The sites differ for rainfall received annually, and therefore, characterized as low to high rainfall zones $[30,62]$. They are located between latitudes $1^{\circ} 11^{\prime}$ and $2^{\circ} 38^{\prime} \mathrm{S}$ and between longitudes $31^{\circ} 18^{\prime}$ $31^{\circ} 46^{\prime} \mathrm{E}$ with altitude ranging from 1159 - 1419 meters above sea level (m. a. s. 1.). The landform of the study sites is almost flat to peneplain with slope ranging from $1-3 \%$. Annual rainfall ranged from $600-2500 \mathrm{~mm}$ with mean annual temperature ranging from $22-23^{\circ} \mathrm{C}[63,30]$.

Table 1. Site characteristics of the representative study sites in Bukoba, Missenyi and Biharamulo Districts, Tanzania.

\begin{tabular}{|c|c|c|c|}
\hline District & Bukoba & Missenyi & Biharamulo \\
\hline Village & Butairuka village & Mabuye Village & Rukaragata village \\
\hline Location & TARI-Maruku & Mabuye Primary School & Rukaragata Farmers' Extension Centre \\
\hline Attributes & Description & & \\
\hline Pedon identification & MARU-P1 & MISSE-P1 & BIHA-P1 \\
\hline Agro-Ecological Zone & High rainfall zone & Medium rainfall zone & Low rainfall zone \\
\hline \multirow{2}{*}{ Coordinates } & $\mathrm{S} 01^{\circ} 25^{\prime} 01.7^{\prime \prime}$ & $\mathrm{S} 01^{\circ} 11^{\prime} 38.1^{\prime \prime}$ & $\mathrm{S} 02^{\circ} 38^{\prime} 52.1^{\prime \prime}$ \\
\hline & E $031^{\circ} 46^{\prime} 39.4^{\prime \prime}$ & E $031^{\circ} 26^{\prime} 00.8^{\prime \prime}$ & E $031^{\circ} 18^{\prime} 49.3^{\prime \prime}$ \\
\hline Landform & Peneplain & Almost flat & Peneplain \\
\hline Geology/Lithology & $\begin{array}{l}\text { Weathered Ankolean system which } \\
\text { resulted to Bukoban system } \\
\text { dominated by shales and sandstones }\end{array}$ & $\begin{array}{l}\text { Quaternary sediment deposits } \\
\text { (sandy, silty, clayey alluvium) }\end{array}$ & $\begin{array}{l}\text { Karagwe-Ankolean system (shale, } \\
\text { quartzic sandstones, quartzites, and } \\
\text { schists) }\end{array}$ \\
\hline Slope gradient $(\%)$ & $1-3$ & $1-2$ & $1-3$ \\
\hline Land use/Vegetation & $\begin{array}{l}\text { Rainfed agriculture (cassava, maize, } \\
\text { sweet potato, banana, coffee and } \\
\text { beans) }\end{array}$ & $\begin{array}{l}\text { Rainfed agriculture (cassava, } \\
\text { maize, sweet potato, banana, coffee } \\
\text { and beans) }\end{array}$ & $\begin{array}{l}\text { Rainfed agriculture (cassava, maize, } \\
\text { sweet potato, banana, coffee and } \\
\text { beans) }\end{array}$ \\
\hline Natural vegetation & $\begin{array}{l}\text { Meopsis eminii "muhumula" Acacia } \\
\text { sp. and grassland ("couch grasses" } \\
\text { Eragrostis spp and Hyparrhenia spp.) }\end{array}$ & $\begin{array}{l}\text { Acacia sp. and grassland (couch } \\
\text { grasses, Themeda triandra, } \\
\text { Hyparrhenia spp. Eragrostis sp. } \\
\text { and Euphobia spp. }\end{array}$ & $\begin{array}{l}\text { Miombo woodlands, grassland (couch } \\
\text { grasses, Hyparrhenia spp. Eragrostis } \\
\text { spp., and Euphobia spp.) }\end{array}$ \\
\hline Natural drainage & Well drained & Well drained & Well drained \\
\hline Flooding & None & None & None \\
\hline Erosion & Water erosion (Sheet/interill) & Water erosion (Sheet/interill) & Water erosion (Sheet/interill) \\
\hline Annual rainfall $(\mathrm{mm})$ & $900-2500$ & $700-1300$ & $600-1000$ \\
\hline Soil moisture regime (SMR) & Udic & Udic & Udic \\
\hline Mean annual temperature $\left({ }^{\circ} \mathrm{C}\right)$ & 22 & 23 & 22 \\
\hline Soil temperature regime (STR) & Isohyperthermic & Isohyperthermic & Isohyperthermic \\
\hline
\end{tabular}

TMRK = TARI Maruku (Tanzania Agricultural Research Institute), Maruku Centre; MBYP = Mabuye Primary School; RKRF = Rukaragata Farmers' Extension Centre; MARU-P1 = Maruku profile 1; MISSE-P1 = Missenyi profile 1; BIHA-P1 = Biharamulo profile 1 
The study sites have Udic SMR and Isohyperthemic STR. Other characteristics are as presented in Table 1. The variations of annual and mean monthly rainfall over sixteen years (2004 to 2019) in the study area are presented in Figures 3 and 4. Annual rainfall in the study area varies from year to year. Within the sixteen years, annual rainfall ranged from $561-3424 \mathrm{~mm}$. The highest annual rainfall $(3324 \mathrm{~mm})$ was recorded in Bukoba District during 2019 while the lowest annual rainfall $(561 \mathrm{~mm})$ was recorded in Biharamulo
District during 2017 (Figure 4). Generally, Bukoba District experienced highest annual rainfall followed by Missenyi District and the least was Biharamulo District. This conforms to the report by $[30,62]$ who reported that Bukoba District is a high rainfall zone, Missenyi District is a medium rainfall zone and Biharamulo District is low rainfall zone. The study sites experiences a bimodal rainfall distribution between September to December (short rains) and March to June (long rains) [29, 30].

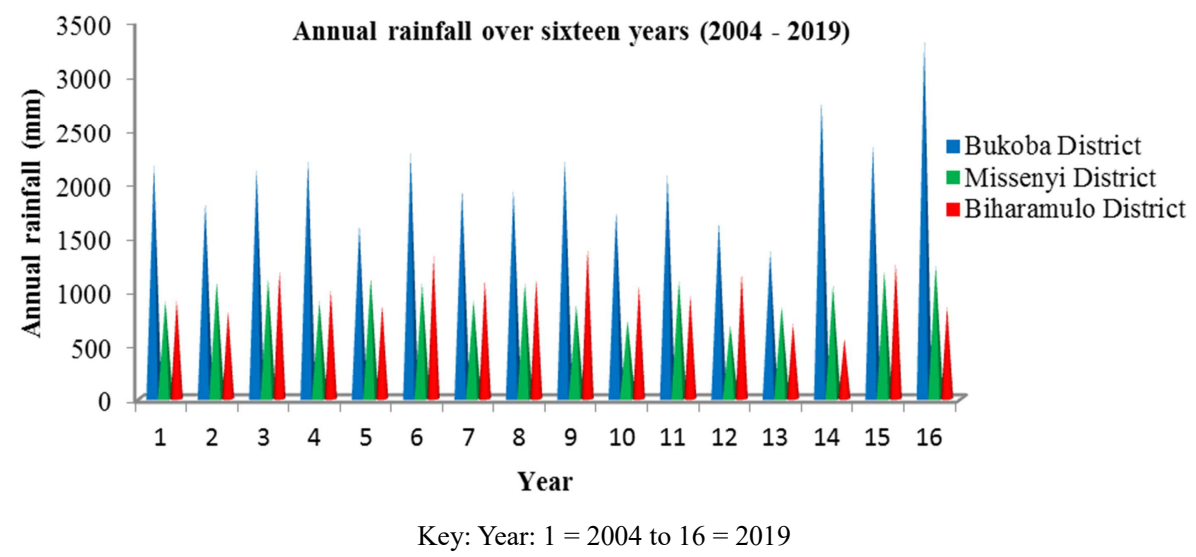

Figure 4. Annual rainfall variation over sixteen years in Bukoba Rural, Missenyi and Biharamulo Districts, Tanzania.

Mean monthly rainfall within the sixteen years (2004 to 2019) ranged from 2 - $359 \mathrm{~mm}$. Bukoba District experienced the highest mean monthly rainfall $(359 \mathrm{~mm})$ followed by Missenyi District $(200 \mathrm{~mm})$ and Biharamulo District experienced the lowest mean monthly rainfall $(163 \mathrm{~mm})$ (Figure 4). In all districts, the months with highest rainfall were from February to May (long rains, Masika), with the range from 53 - $324 \mathrm{~mm}$ as compared to from August to December (short rains, Vuli), with the range from 48 - 191 mm (Figure 5). The month with peak mean monthly rainfall was April followed by May in Bukoba and Missenyi Districts. In Biharamulo District, the month with peak mean monthly rainfall was March followed by April (Figure 5). However, few rains were experienced from June to August, but there was no month within the year that did not experience rainfall at all. That is why the study area has been characterized to have Udic soil moisture regime (SMR) [41].

Mean monthly rainfall over sixteen years (2004 - 2019)

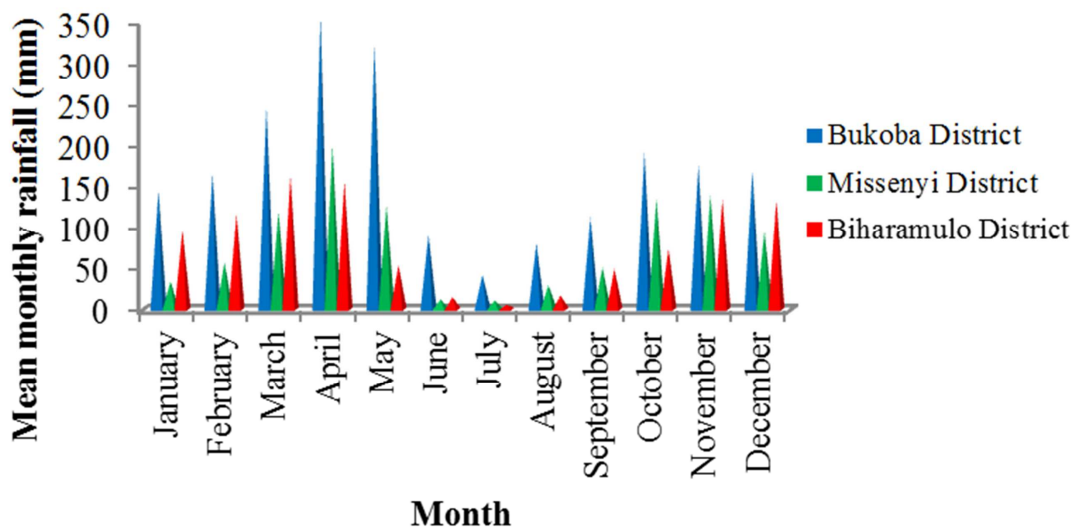

Figure 5. Mean monthly rainfall variation over sixteen years in Bukoba, Missenyi and Biharamulo Districts, Tanzania.

\subsection{Soil Morphological Characteristics of the Studied Pedons}

The studied pedons were named as MARU-P1, MISSE-P1 and BIHA-P1 for Bukoba, Missenyi and Biharamulo Districts, respectively. The effective soil depths ranged from $0-200+\mathrm{cm}$ whereby that of MARU-P1 ranged from $0-$ 200+ cm, MISSE-P1 from $0-187+\mathrm{cm}$ and BIHA-P1 from 0 $-170+\mathrm{cm}$ (Table 2). Thus, all studied pedons were very deep [32]. At the time of observation, MARU-P1 pedon was moist and therefore, the colour of dry soil was not determined. For 
MISSE-P1 and BIHA-P1 pedons, colours of dry topsoils were dark grey and brow, respectively. Dry subsoil colour was black for MISSE-P1 and ranged from brown to yellowish red for BIHA-P1. Moist colour of the topsoils were very dark brown, black and dark brown for MARU-P1, MISSE-P1 and BIHA-P1, respectively, while moist colour of subsoil ranged from dark brown to strong brown (MARUP1), dark brown to grey (MISSE-P1) and dark brown to yellowish red (BIHA-P1). Consistencies of the pedons were slightly hard to very hard when dry, friable when moist and slightly sticky and slightly plastic when wet, for the topsoils of all pedons, and ranged from very friable to friable when moist and non-sticky to sticky and non-plastic to plastic when wet, for subsoils of all pedons (Table 2). Soil structure of the pedons were moderate, fine and medium, columnar (MARU-P1), moderate, medium and coarse, columnar (MISSE-P1), and moderate, medium, subangular blocky for topsoils. For the subsoils, the structures were moderate, medium, subangular blocky to weak, fine and medium, subangular blocky (MARU-P1), weak, medium and coarse, subangular blocky to single grain (structure less) (MISSEP1) and moderate, medium and coarse, subangular blocky to moderate and strong, medium and fine, subangular blocky (BIHA-P1). Horizon boundaries of topsoils were clear and wavy in all pedons and ranged from gradual and wavy to diffuse and smooth (MARU-P1), abrupt and wavy to abrupt and smooth (MISSE-P1) and gradual and smooth to diffuse and smooth (BIHA-P1) for the subsoils. Other morphological features were as presented in Table 2 and Figure 6. Also at the time of observation, water-logging condition was observed at a depth of $167 \mathrm{~cm}$ in MISSE-P1 pedon, associated with greying condition in which distinct pattern of mottling was observed which reflects alternating conditions of reduction and oxidation (Redox) of sesquioxides (oxides of $\mathrm{Al}$ and $\mathrm{Fe}$ ) caused by seasonal water-logging condition [32]. Other researchers, [64] working on the grey soil of Bangladesh floodplain, [65] working on rice soils of Tropical Rainforest in Southeastern Nigeria and [6] working on soils of Kilombero valley in Tanzania observed similar conditions in the subsoils. The redoximorphic condition together with stratification observed in Missenyi pedon signified alluvial soil formation. However, the observed water-logging condition could not affect the growth of crops since the condition was seasonal and observed at a very deep (167+ $\mathrm{cm})$ horizon. The other two pedons (MARU-P1 and BIHAP1) were free from water-logging condition. The observed soil structures in all studied pedons favoured crop growth due to the ability to allow root proliferation, aeration, water storage and infiltration [66].

Table 2. Morphological features of studied pedons in Bukoba, Missenyi and Biharamulo Districts, Tanzania.

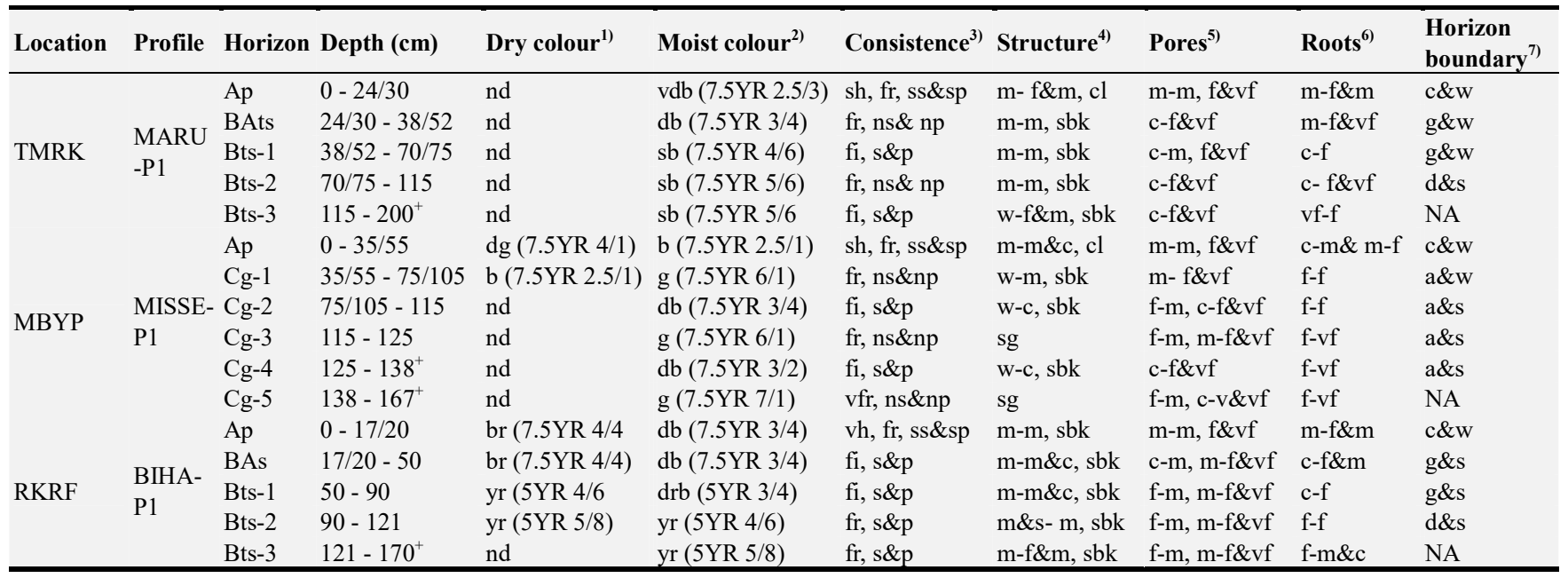

TMRK = TARI Maruku (Tanzania Agricultural Research Institute, Maruku Centre); MBYP = Mabuye Primary School; RKRF = Rukaragata Farmer's Extension Centre; MARU-P1 = Maruku profile 1; MISSE-P1 = Missenyi profile 1; BIHA-P1 = Biharamulo profile 1 ; nd = not determined; NA = not applicable

${ }^{1) ; 2)}$ Soil colour: $\mathrm{g}=$ gray; $\mathrm{dg}=$ dark gray; $\mathrm{b}=$ black; $\mathrm{br}=$ brown; $\mathrm{yr}=$ yellowish red; $\mathrm{db}=$ dark brown; vdb = very dark brown; sb = strong brown; drb = dark reddish brown

3) Consistence: $\mathrm{sh}=$ slightly hard; $\mathrm{h}=$ hard; $\mathrm{vh}=$ very hard; $\mathrm{fr}=$ friable; vfr = very friable; fi = firm; $\mathrm{ns} \& \mathrm{np}=$ non-sticky and non-plastic; ss\&sp = slightly sticky and slightly plastic; s\&p = sticky and plastic

${ }^{4)}$ Structure:' $\mathrm{m}$ - $\mathrm{f} \& \mathrm{~m}=$ moderate fine and medium; $\mathrm{m}-\mathrm{m}=$ moderate medium; $\mathrm{w}-\mathrm{f} \& \mathrm{~m}=$ weak fine and medium; $\mathrm{m}-\mathrm{m} \& \mathrm{c}=\mathrm{moderate}$ medium and coarse; $\mathrm{w}-\mathrm{m}$ $=$ weak medium; $\mathrm{w}-\mathrm{c}=$ weak coarse $; \mathrm{sg}=$ single grain $; \mathrm{m}-\mathrm{m} \& \mathrm{c}=$ moderate medium and coarse; $\mathrm{m} \& \mathrm{~s}-\mathrm{m}=$ moderate and strong medium; $\mathrm{cl}=\mathrm{columnar} ; \mathrm{sbk}=$ subangular blocky

${ }^{5)}$ Pores:' $\mathrm{m}-\mathrm{m}, \mathrm{f} \& \mathrm{vf}=$ many medium, fine and very fine; $\mathrm{c}-\mathrm{f} \& \mathrm{vf}=$ common fine and very fine; $\mathrm{c}-\mathrm{m}, \mathrm{f} \& \mathrm{vf}=\mathrm{common} \mathrm{medium}$, fine and very fine; $\mathrm{m}-\mathrm{f} \& \mathrm{vf}=$ many fine and very fine; $\mathrm{f}-\mathrm{m}, \mathrm{c}-\mathrm{f} \& \mathrm{vf}=$ few medium, common fine and very fine, $\mathrm{c}-\mathrm{m}, \mathrm{m}-\mathrm{f} \& \mathrm{vf}=$ common medium, many fine and very fine; $\mathrm{f}-\mathrm{m}$, $\mathrm{m}-\mathrm{f} \& \mathrm{vf}=$ few medium, many fine and very fine

${ }^{6)}$ Roots:' $\mathrm{m}-\mathrm{f} \& \mathrm{~m}=$ many fine and medium; $\mathrm{m}-\mathrm{f} \& \mathrm{vf}=$ many fine and very fine; $\mathrm{c}-\mathrm{f}=\mathrm{common}$ fine; $\mathrm{c}-\mathrm{f} \& \mathrm{vf}=\mathrm{common}$ fine and very fine; $\mathrm{vf}-\mathrm{f}=\mathrm{very}$ few fine; $\mathrm{c}-\mathrm{m} \& \mathrm{~m}-\mathrm{f}=$ common medium and many fine; $\mathrm{f}-\mathrm{f}=\mathrm{few}$ fine; $\mathrm{f}-\mathrm{vf}=$ few very fine; $\mathrm{c}-\mathrm{f} \& \mathrm{~m}=$ common fine and medium; $\mathrm{f}-\mathrm{m} \& \mathrm{c}=\mathrm{few}$ medium and coarse

7) Horizon boundary: $\mathrm{c} \& \mathrm{w}=$ clear and wavy; $\mathrm{g} \& \mathrm{w}=$ gradual and wavy; $\mathrm{d} \& \mathrm{w}=$ diffuse and wavy; d\&s = diffuse and smooth; a\&w $=\mathrm{abrupt}$ and wavy; a\&s = abrupt and smooth; g\&s = gradual and smooth . 


\subsection{Some Physical Properties of the Studied Pedons in Bukoba, Missenyi and Biharamulo Districts}

Some of physical properties of the studied pedons presented in this study include soil texture, bulk density, porosity, penetration resistance and soil moisture retention characteristics.

\subsubsection{Soil Texture, Penetration Resistance and Silt:Clay Ratio}

Soil texture influences other soil properties like soil structure, root penetrability, soil fertility consistence, soil moisture regime, workability, infiltration rate, runoff rate, erodibility and permeability of the soil [53]. Soil textures of the studied pedons were sandy clay loam in the topsoil and clay in the subsoils (MARU-P1) in Bukoba District, sandy loam in the topsoil and sandy clay loam in the subsoils (MISSE-P1) in Missenyi District and sandy clay throughout the BIHA-P1 pedon in Biharamulo District. Soil penetration resistance increased with increased bulk density and with decreased total porosity and plant available moisture content (Table 3 and Figure 5). Other researchers [67, 16] reported similar results. The observed soil textures of the studied pedons, favour crop production since they allow root proliferation, aeration, water infiltration and holding capacity, soil nutrient retention and drainage $[66,68]$. Among the three pedons, MARU-P1 had heavier texture in the subsoil compared to the other pedons due to increased clay with depth, which is an indication of clay eluviationilluviation process [69], as also supported by the presence of clay illuviation features notably clay cutans in the subsoils. This implied that pedon MARU-P1, had higher water holding potential and nutrients retention capacity [70] than the other two pedons. Other researchers [16, 6, 9] observed clay increase with depth in the studies done on the soils of Busia County Western Kenya, Kilombero Valley Tanzania and southern Tanzania, respectively.

Penetration resistance of the soils is used to assess the physical quality of cultivated soils. It indicates the presence or absence of problems related to soil compaction which has direct relationship with root growth [71]. Penetration resistance of the studied pedons were $2.1 \mathrm{MPa}$ in the topsoil and increased to $2.2 \mathrm{MPa}$ throughout the subsoil of MARU$\mathrm{P} 1$ pedon and 2.4 MPa in the topsoil and increased from 2.4 $2.9 \mathrm{MPa}$ in the subsoils between $75-125 \mathrm{~cm}$ depth followed by a decrease from $2.4-1.7 \mathrm{MPa}$ between $125-167$ depth in MISSE-P1 pedon. In BIHA-P1 pedon, penetration resistance was $2.5 \mathrm{MPa}$ in the topsoil and increased from $3.3-3.4$ between 20 - $90 \mathrm{~cm}$ depth followed by a decrease from 2.0 1.9 MPa between $90-170 \mathrm{~cm}$ depth. The results indicated irregularity in the increase of penetration resistance in MISSE-P1 and BIHA-P1 pedons. This may be attributed to illuvial deposition of surface materials into the lower horizons of the pedons as observed in MISSE-P1 pedon (Figure 3).

Table 3. Some physical properties of the studied pedons in Bukoba, Missenyi and Biharamulo Districts, Tanzania.

\begin{tabular}{|c|c|c|c|c|c|c|c|c|c|c|c|}
\hline Location & Pedon & Horizon & Depth (cm) & Sandy (\%) & $\begin{array}{l}\text { Clay } \\
(\%)\end{array}$ & $\begin{array}{l}\text { Silt } \\
(\%)\end{array}$ & $\begin{array}{l}\text { Textural } \\
\text { class }\end{array}$ & $\begin{array}{l}\text { Bulk density } \\
\left(\mathrm{Mg} \mathrm{m}^{-3}\right)\end{array}$ & $\begin{array}{l}\text { Porosity } \\
(\%)\end{array}$ & $\begin{array}{l}\text { Penetration } \\
\text { resistance (MPa) }\end{array}$ & $\begin{array}{l}\text { Silt:clay } \\
\text { ratio }\end{array}$ \\
\hline \multirow{4}{*}{ TMRK } & \multirow{4}{*}{$\begin{array}{l}\text { MARU- } \\
\text { P1 }\end{array}$} & Ap & $0-24 / 30$ & 64.82 & 21.90 & 13.28 & SCL & 0.70 & 73.10 & 2.1 & 0.06 \\
\hline & & BAts & $24 / 30-38 / 52$ & 58.82 & 29.90 & 11.28 & SCL & 1.10 & 54.40 & 2.2 & 0.38 \\
\hline & & Bts-2 & $70 / 75-115$ & 32.80 & 63.92 & 3.28 & $\mathrm{C}$ & 1.20 & 45.50 & 2.2 & 0.05 \\
\hline & & Bts-3 & $115-200^{+}$ & 31.82 & 63.90 & 4.28 & $\mathrm{C}$ & nd & nd & 2.2 & nd \\
\hline \multirow{5}{*}{ MBYP } & \multirow{5}{*}{$\begin{array}{l}\text { MISSE- } \\
\text { P1 }\end{array}$} & Ap & $0-35 / 55$ & 75.80 & 16.92 & 7.28 & SL & 1.20 & 47.00 & 2.4 & 0.43 \\
\hline & & $\mathrm{Cg}-2$ & $75 / 105-115$ & 63.08 & 32.64 & 4.28 & SCL & 1.30 & 46.30 & 2.9 & 0.13 \\
\hline & & $\mathrm{Cg}-3$ & $115-125$ & 78.08 & 16.64 & 5.28 & SCL & nd & nd & 2.9 & nd \\
\hline & & $\mathrm{Cg}-4$ & $125-138$ & 67.08 & 27.64 & 5.28 & SCL & nd & nd & 2.4 & nd \\
\hline & & $\mathrm{Cg}-5$ & $138-167^{+}$ & 78.08 & 21.64 & 0.28 & SCL & 1.60 & 41.70 & 1.7 & 0.01 \\
\hline \multirow{4}{*}{ RKRF } & \multirow{4}{*}{ BIHA-P1 } & Ap & $0-17 / 20$ & 53.08 & 40.64 & 6.28 & $\mathrm{SC}$ & 1.10 & 53.70 & 2.5 & 0.15 \\
\hline & & BAs & $17 / 20-50$ & 43.08 & 46.64 & 5.28 & $\mathrm{SC}$ & nd & nd & 3.3 & 0.07 \\
\hline & & Bts-1 & $50-90$ & 47.08 & 49.64 & 3.28 & $\mathrm{SC}$ & 1.40 & 45.50 & 3.4 & nd \\
\hline & & Bts-2 & $90-121$ & 46.08 & 50.64 & 3.28 & $\mathrm{SC}$ & nd & nd & 2.0 & 0.06 \\
\hline
\end{tabular}

TMRK = TARI Maruku (Tanzania Agricultural Research Institute, Maruku Centre); MBYP = Mabuye Primary School; RKRF = Rukaragata Farmer's Extension Centre; MARU-P1 = Maruku profile 1; MISSE-P1 = Missenyi profile 1; BIHA-P1 = Biharamulo profile 1; SCL = sandy clay loam; SL = sandy loam; $\mathrm{SC}=$ sandy clay; $\mathrm{C}=\mathrm{Clay} ; \mathrm{nd}=$ not determined

The observed lower penetration resistance in the topsoil than in the subsoil of the studied pedons is associated with the lower soil compaction in topsoil than in subsoil, which corresponds to the observed lower BD and higher porosity values in topsoil (Table 3). Other researchers [16, 72, 6] reported similar trends. However, [16, 37] reported that penetration resistance of $>3.0 \mathrm{MPa}$ signifies compaction that can impair growth and development of crops. Based on this inference therefore, the soils (top and subsoils) of MARU-P1 and MISSE-P1 pedons and topsoil of BIHA-P1 pedon would favour growth and development of the crops.

Silt:clay ratio signifies the aging of the soil whereby the lower the ratio the more weathered the soil is [73]. The levels of silt:clay ratio ranged from $0.05-0.61$ in MARU-P1, from $0.01-0.43$ in MISSE-P1 and from $0.06-0.15$ in BIHA-P1. In all pedons, silt:clay ratio decreased with increasing depth, 
indicating higher degree of weathering in the subsoils than in the topsoils. This conforms to the trends reported by [74] working on the soils of Meatu District, Tanzania. Moreover, the higher level of silt:clay ratio in the topsoils than in the subsoils signified the presence of more clay in the subsoils than in the topsoils of the studied pedons, probably due to clay illuviation process [66].

\subsubsection{Soil Bulk Density and Porosity}

Bulk density (BD) of the soil describes soil quality [75]. Bulk densities of the studied pedons were $0.70 \mathrm{Mg} \mathrm{kg}^{-1}$ in topsoil and ranged from $1.10-1.20 \mathrm{Mg} \mathrm{kg}^{-1}$ in subsoils of MARU-P1, $1.20 \mathrm{Mg} \mathrm{kg}^{-1}$ in topsoil and ranged from 1.30 $1.60 \mathrm{Mg} \mathrm{kg}^{-1}$ in subsoils of MISSE-P1 and $1.10 \mathrm{Mg} \mathrm{kg}^{-1}$ in topsoil and ranged from $1.40-1.50 \mathrm{Mg} \mathrm{kg}^{-1}$ in subsoils of BIHA-P1. Pedon MISSE-P1 had the highest $\left(1.20 \mathrm{Mg} \mathrm{kg}^{-1}\right)$ bulk density while MARU-P1 had the lowest $\left(0.70 \mathrm{Mg} \mathrm{kg}^{-1}\right)$ bulk density in topsoils. The same trend was observed in subsoils of the three pedons (Table 3). In all pedons, bulk density increased with depth. [66] reported that soil bulk density usually increases with depth since subsurface layers are more compacted and have less organic matter, aggregation, and root penetration compared to surface layers. The higher BD values in subsoils than in topsoils of the studied pedons may pose a slight limitation to root penetration and water movement [9]. Similar trends of bulk density increase with depth was observed by [65] working on tropical rainforest of Nigeria, [6] working on the soils of Kilombero Valley, Tanzania and [9] working on the soils of southern Tanzania. Bulk density value of $>1.65 \mathrm{Mg} \mathrm{kg}^{-1}$ is unfavourable to root growth in sandy clay loams and clay loams $[53,66]$. Therefore, the observed BD values in the studied pedons are favourable for root proliferation, hence crop growth and development.

Soil porosity of the studied pedons were $73.10 \%$ in topsoil and ranged from $45.50-54.40 \%$ in subsoils of MARU-P1 pedon, $47 \%$ in topsoil and ranged from $46.30-41-70 \%$ in subsoils of MISSE-P1 pedon, and 53.70\% in topsoil and ranged from $44.00-45.50 \%$ in subsoils of BIHA-P1 pedon. Pedon MARU-P1 had the highest $(73.10 \%)$ porosity while pedon MISSE-P1 had the lowest $(47 \%)$ porosity in topsoil. The same trend was observed in subsoils of the pedons (Table 3). Unlike bulk density, soil porosity decreased with depth in all pedons. This showed an inverse relationship with bulk density since porosity is calculated from the relationship between bulk density and particle density of soil as porosity $=1$-(bulk density/particle density) $[53,67,66]$. The higher soil porosity in topsoils than in subsoils in the studied pedons was an indication that topsoils were uncompacted and well granulated [66], a condition which favours root proliferation and therefore, growth and development of the crops.

\subsubsection{Soil Moisture Retention Characteristics, Plant Available Water and Moisture Content}

Soil water retention characteristics of the studied pedons are presented in Figure 6. The presented moisture characteristic curves indicated the decrease in soil moisture with increased soil moisture suction. Pedon MARU-P1 held more soil moisture at any soil moisture suction than BIHA-P1 and MISSE-P1 pedons. The topsoil of MARU-P1 and BIHA-P1 pedons had more moisture than the intermediate and subsoil following a trend of topsoil $>$ subsoil $>$ intermediate. However, in MISSE-P1 pedon, the subsoil had more moisture than topsoil and intermediate with a trend of subsoil > topsoil $>$ intermediate. This might be due to seasonal water-logging condition observed in the lower horizon $(167+\mathrm{cm}$ depth) of MISSE-P1 pedon. There was more drastic decrease in soil moisture with increased soil moisture suction in pedon MISSE-P1 than in MARU-P1 and BIHA-P1 pedons due to differences in soil texture among the studied pedons. The soil texture of the studied pedons ranged from sandy clay loam to clay (MARU-P1), sandy loam to sandy clay loam (MISSE-P1) and sand clay throughout the pedon in BIHA-P1 (Table 3). The observed more soil moisture with a gradual decrease upon increased soil moisture suction in MARU-P1 than pedons MISSE-P1 and BIHA-P1 was due to high clay content in MARU-P1 pedon. Other researchers [16, 76, 6] reported similar results. In addition, less soil moisture with a drastic decrease upon increased soil moisture suction in MISSE-P1 suggested the potential of the soil to dryness especially during dry spell $[16,76,6]$.

Soil moisture content and plant available water of the studied pedons ranged from 51.00 - 68. 60\% (Figure 7). Pedon MISSE-P1 had higher (59.00 - 68.60\%) moisture content than BIHA-P1 (60.40 - 63.10\%) and MARU-P1 $(51.00-53.70 \%)$ pedons. The same trend was observed in plant available water. In all studied pedons, moisture content increased with depth while plant available water decreased with increasing depth in MARU-P1 and MISSE-P1 pedons but increased with depth in BIHA-P1 pedon (Figure 7). The lower plant available water in the topsoil than in the subsoils in pedon BIHA-P1, might be due to presence of a thin Ap horizon $(0-20 \mathrm{~cm})$ in BIHA-P1 as compared to pedons MARU-P1 (0 - $30 \mathrm{~cm})$ and MISSE-P1 $(0-35 \mathrm{~cm})$. Therefore, more water was potentially available to plants in MISSE-P1 (107 mm) followed by MARU-P1 $(86.40 \mathrm{~mm})$ and the least was BIHA-P1 (35 mm).
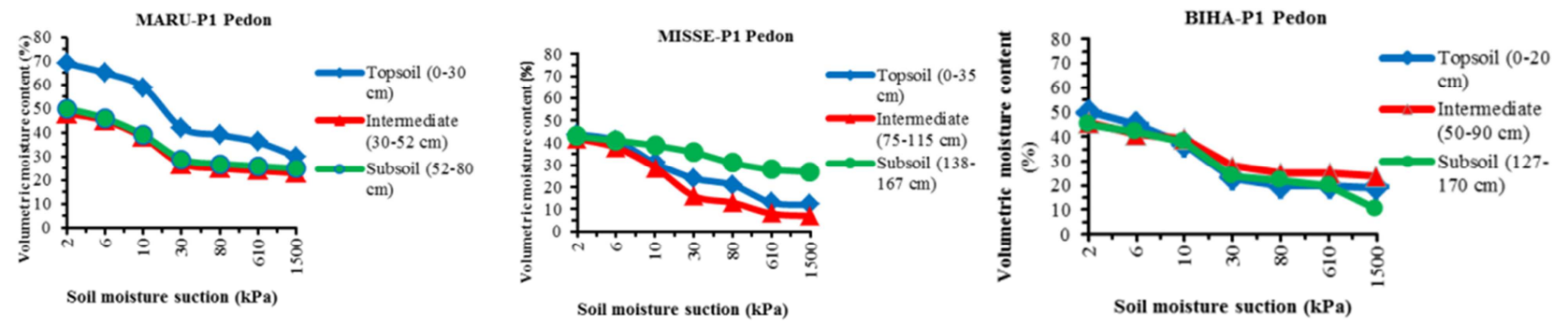

Figure 6. Soil moisture characteristics of pedons MARU-P1, MISSE-P1 and BIHA-P1, Tanzania. 


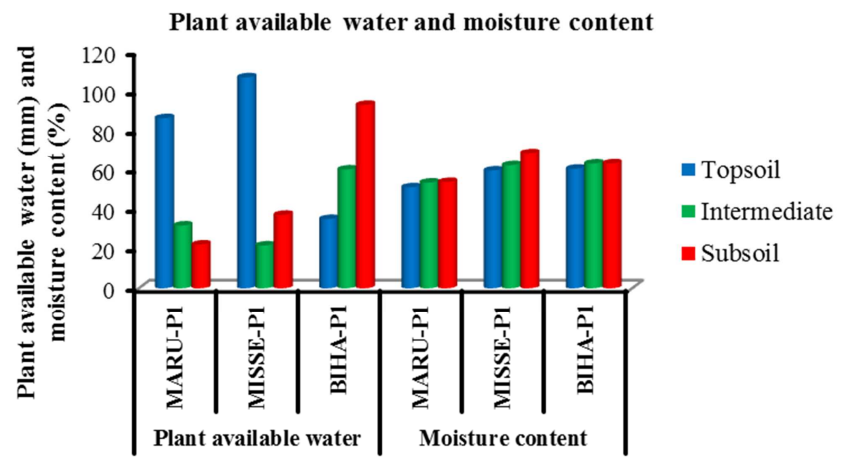

Figure 7. Plant available water and moisture content of the studied pedons. in Bukoba, Missenyi and Biharamulo Districts, Tanzania.

\subsection{Soil Chemical Properties of the Studied Pedons}

Some chemical properties of the studied pedons presented in this study include, soil $\mathrm{pH}$, electrical conductivity (EC), soil organic matter (OC), total nitrogen (TN), carbon: nitrogen $(\mathrm{C}: \mathrm{N})$ ratio, available phosphorus $(\mathrm{P})$, exchangeable bases, cation exchange capacity (CEC), exchangeable sodium percentage (ESP), percent base saturation (PBS), nutrient balance, micronutrients, total elemental composition and weatherability potential.

\subsubsection{Soil pH and Electrical Conductivity (EC)}

The soil $\mathrm{pH}$ in water solution of the studied pedons ranged from medium acid (5.82) to very strong acid (5.00) [77, 42, 53, $78,5]$. The individual pedons had the following soil $\mathrm{pH}$ levels: MARU-P1 ranged from strong acid (5.46) to very strong acid (5.00), MISSE-P1 ranged from medium acid (5.82) to strong acid (5.08) and BIHA-P1 from medium acid (5.57) to strong acid (5.15) (Table 4). Generally, in all studied pedons, soil $\mathrm{pH}$ decreased with depth probably due to the acidic nature of the parent materials of the study area whereby higher contents of oxides of aluminum $\left(\mathrm{Al}_{2} \mathrm{O}_{3}\right)$ predominate in the subsoils (Table 8). The $\mathrm{pH}$ of the topsoils was strong acidic (5.12) for MARU-P1 and medium acid for MISSE-P1 (5.82) and BIHA$\mathrm{P} 1$ (5.57). This may be due to the reason that pedon MARU-P1 is in the high rainfall zone with high leaching potential whereas MISSE-P1 and BIHA-P1 are in medium and low rainfall zones, respectively $[30,62]$. Leaching removes the basic cations from the topsoil to the subsoil leaving more $\mathrm{H}^{+}$in the topsoil, resulting more acidic conditions in the topsoil [66]. The $\mathrm{pH}_{\mathrm{KCl}}$ values of all the studied pedons were consistently lower than $\mathrm{pH}_{\text {water }}$ values implying that the soils have net negative charge [7]. Other researchers [53, 66, 16] reported that acidic soils with low $\mathrm{pH}(<5.5)$ have a great potential to cause $\mathrm{Al}, \mathrm{Mn}$ and Fe toxicity, deficiencies of some essential nutrients and retardation of microbial activity which ultimately affect the decomposition of soil organic matter. The $\mathrm{pH}$ values of $<5.5$ can also cause the dissolution of aluminum and iron minerals that precipitate with phosphorus leading to P-fixation and further lowering of the soil $\mathrm{pH}[66,16]$. [59] reported that soils with $\mathrm{pH}$ range from 4.5 - 7.0 are favourable for cassava production. Therefore, according to [59], the $\mathrm{pH}$ of the studied pedons is favourable for cassava growth and development.

The electrical conductivity (EC) of the studied pedons was very low $\left(0.01-0.05 \mathrm{dS} \mathrm{m}^{-1}\right)[53,78,5,79]$ throughout the soil depths. $[53,5]$ reported that soil EC values of $<1.7 \mathrm{dS} \mathrm{m}^{-1}$ ) do not cause crop yield reduction but those with EC values ranging from $5.9-10 \mathrm{dS} \mathrm{m}^{-1}$ can cause crop yield reduction up to $100 \%$. In additional, [59] reported that soils with EC of $2-4$ $\mathrm{dS} \mathrm{m}^{-1}$ are fovourable for cassava production. Therefore, according to $[5,59]$, the EC of the studied pedons would favour cassava growth and development.

Table 4. Some chemical properties of the studied pedons in Bukoba, Missenyi and Biharamulo Districts, Tanzania.

\begin{tabular}{|c|c|c|c|c|c|c|c|c|c|c|c|}
\hline Location & Pedon & Horizon & Depth (cm) & $\mathrm{pH}\left(\mathrm{H}_{2} \mathrm{O}\right)$ & pH (KCI) & $\mathrm{EC}\left(\mathrm{dS} \mathrm{m} \mathrm{m}^{-1}\right)$ & OC (\%) & OM (\%) & TN (\%) & C:N ratio & $\begin{array}{l}\text { Bray-1. P } \\
\left(\mathrm{mg} \mathrm{kg}^{-1}\right)\end{array}$ \\
\hline \multirow{5}{*}{ TMRK } & \multirow{5}{*}{ MARU-P1 } & Ap & $0-24 / 30$ & $5.12 \mathrm{STA}$ & 4.18 ETA & $0.02 \mathrm{VL}$ & $3.20 \mathrm{H}$ & $5.50 \mathrm{M}$ & $0.44 \mathrm{M}$ & $8 \mathrm{GQ}$ & $6.17 \mathrm{~L}$ \\
\hline & & BAts & $24 / 30-38 / 52$ & 5.46 STA & 4.15 ETA & $0.01 \mathrm{VL}$ & $2.20 \mathrm{M}$ & $3.78 \mathrm{M}$ & $0.32 \mathrm{M}$ & $8 \mathrm{GQ}$ & $3.95 \mathrm{~L}$ \\
\hline & & Bts-1 & $38 / 52-70 / 75$ & 5.11 STA & 3.90 ETA & $0.01 \mathrm{VL}$ & $1.30 \mathrm{M}$ & $2.24 \mathrm{M}$ & $0.13 \mathrm{~L}$ & $10 \mathrm{GQ}$ & $3.26 \mathrm{~L}$ \\
\hline & & Bts-2 & $70 / 75-115$ & $5.01 \mathrm{STA}$ & 3.71 ETA & $0.01 \mathrm{VL}$ & $0.90 \mathrm{~L}$ & $1.55 \mathrm{M}$ & $0.08 \mathrm{VL}$ & $11 \mathrm{GQ}$ & $3.15 \mathrm{~L}$ \\
\hline & & Bts-3 & $115-200^{+}$ & 5.00 VSTA & 3.70 ETA & $0.01 \mathrm{VL}$ & $0.90 \mathrm{~L}$ & $1.55 \mathrm{M}$ & $0.07 \mathrm{vl}$ & $13 \mathrm{GQ}$ & $3.08 \mathrm{~L}$ \\
\hline \multirow{5}{*}{ MBYP } & \multirow{5}{*}{ MISSE-P1 } & Ap & $0-35 / 55$ & $5.82 \mathrm{MA}$ & 4.78 ETA & $0.05 \mathrm{VL}$ & $1.20 \mathrm{~L}$ & $2.06 \mathrm{M}$ & $0.10 \mathrm{~L}$ & 12 GQ & $41.98 \mathrm{H}$ \\
\hline & & $\mathrm{Cg}-2$ & $75 / 105-115$ & $5.74 \mathrm{MA}$ & 4.93 ETA & $0.02 \mathrm{VL}$ & $0.70 \mathrm{~L}$ & $1.20 \mathrm{~L}$ & $0.04 \mathrm{VL}$ & $18 \mathrm{MQ}$ & $7.38 \mathrm{M}$ \\
\hline & & $\mathrm{Cg}-3$ & $115-125$ & 5.32 STA & 4.37 ETA & $0.01 \mathrm{VL}$ & $0.70 \mathrm{~L}$ & $1.20 \mathrm{~L}$ & $0.04 \mathrm{VL}$ & $18 \mathrm{MQ}$ & $7.38 \mathrm{M}$ \\
\hline & & $\mathrm{Cg}-4$ & $125-138^{+}$ & 5.27 STA & 4.06 ETA & $0.01 \mathrm{VL}$ & $0.60 \mathrm{~L}$ & $1.03 \mathrm{~L}$ & $0.04 \mathrm{VL}$ & $15 \mathrm{MQ}$ & $6.47 \mathrm{~L}$ \\
\hline & & $\mathrm{Cg}-5$ & $138-167$ & 5.08 STA & 4.01 ETA & $0.01 \mathrm{VL}$ & $0.50 \mathrm{VL}$ & $0.86 \mathrm{~L}$ & $0.04 \mathrm{VL}$ & $13 \mathrm{MQ}$ & $6.07 \mathrm{~L}$ \\
\hline \multirow{4}{*}{ RKRF } & \multirow{4}{*}{ BIHA-P1 } & Ap & $0-17 / 20$ & $5.57 \mathrm{MA}$ & 4.39 ETA & $0.03 \mathrm{VL}$ & $1.70 \mathrm{M}$ & $2.92 \mathrm{H}$ & $0.14 \mathrm{~L}$ & $12 \mathrm{GQ}$ & $6.32 \mathrm{~L}$ \\
\hline & & BAs & $17 / 20-50$ & 5.22 STA & 3.95 ETA & $0.02 \mathrm{VL}$ & $1.20 \mathrm{~L}$ & $2.06 \mathrm{M}$ & $0.11 \mathrm{~L}$ & $11 \mathrm{GQ}$ & $3.39 \mathrm{~L}$ \\
\hline & & Bts-1 & $50-90$ & $5.15 \mathrm{STA}$ & 3.85 ETA & $0.01 \mathrm{VL}$ & $1.00 \mathrm{~L}$ & $1.72 \mathrm{M}$ & $0.06 \mathrm{VL}$ & $17 \mathrm{MQ}$ & $2.49 \mathrm{~L}$ \\
\hline & & Bts-3 & $121-170^{+}$ & 5.46 STA & 4.00 ETA & $0.01 \mathrm{VL}$ & $0.70 \mathrm{~L}$ & $1.20 \mathrm{~L}$ & $0.04 \mathrm{VL}$ & $18 \mathrm{MQ}$ & $1.48 \mathrm{~L}$ \\
\hline
\end{tabular}

TMRK = TARI Maruku (Tanzania Agricultural Research Institute, Maruku Centre); MBYP = Mabuye Primary School; RKRF = Rukaragata Farmer's Extension Centre; MARU-P1 = Maruku profile 1; MISSE-P1 = Missenyi profile 1; BIHA-P1 = Biharamulo profile 1

Chemical property: $\mathrm{OC}=$ organic carbon; $\mathrm{OM}=$ organic matter; $\mathrm{TN}=$ total nitrogen; $\mathrm{C}: \mathrm{N}=$ carbon: nitrogen ratio; $\mathrm{Bray}-1 \mathrm{P}=\mathrm{Bray}-1$ phosphorus; $\mathrm{EC}=$ electric conductivity

Rating: VSTA = very strongly acid; $\mathrm{STA}=$ strongly acid; $\mathrm{MA}=$ medium acid; $\mathrm{ETA}=$ extremely acid; $\mathrm{L}=\mathrm{low} ; \mathrm{VL}=\mathrm{very}$ low; $\mathrm{H}=\mathrm{high} ; \mathrm{M}=$ medium, $\mathrm{GQ}=$ good quality, MQ = moderate quality $[77,42,53,78,5,37,79]$ 


\subsubsection{Soil Organic Carbon (SOC), Total Nitrogen (TN) and Carbon-Nitrogen (C:N) Ratio}

The soil organic carbon (SOC) is a major component of soil organic matter (SOM) and a primary source of nitrogen for plant growth. It also plays a vital role in providing plant nutrients such as phosphorus and sulphur [80, 66]. Soil organic carbon (SOC) of the studied pedons ranged from very low $(0.50 \%)$ to high $(3.20 \%)[77,42,53,78,5]$. The studied pedons had the following SOC levels: In MARU-P1 SOC ranged from low $(0.90 \%)$ to high $(3.20 \%)$, in MISSEP1 from very low $(0.50 \%)$ to low $(1.20 \%)$ and in BIHA-P1 from low $(0.70 \%)$ to medium $(1.70 \%)$. In all pedons, SOC decreased with increasing depth (Table 4) due to presence to high level of organic matter in topsoils of pedons MARU-P1 and BIHA-P1 and medium level of organic matter in topsoil of pedon MISSE-P1. Similar results were reported by [9] and [74] working on the soils of southern Tanzania and Meatu District, Tanzania, respectively. [59] reported that soils with OC ranging from $2-4 \%$ are favourable for cassava production. Therefore, according to [59], only OC of MARU-P1 pedon could favour cassava growth and development as opposed to pedons MISSE-P1 and BIHA-P1. Thus, improvement of OC of MISSE-P1 and BIHA-P1 pedons is of great importance for growth and development of crops including cassava. This may be achieved through application of organic fertilizers such as farmyard manure and incorporation of organic residues into the soil after crop harvesting [81].

Total nitrogen $(\mathrm{TN})$ in the studied pedons ranged from very low $(0.04 \%)$ to medium $(0.44 \%)$ [77, $42,53,78,5,79]$. The studied pedons had the following total nitrogen levels: In pedon MARU-P1 TN ranged from very low $(0.07 \%)$ to medium $(3.20 \%)$ whereas in pedons MISSE-P1 and BIHAP1 it ranged from very low $(0.04-0.06 \%)$ to low $(0.10$ $0.14 \%)$. In all pedons, $\mathrm{TN}$ decreased with increasing depth (Table 4). In topsoil of MARU-P1, TN was medium while in topsoils of MISSE-P1 and BIHA-P1, TN was low. This is contrary to the high levels of SOC and SOM observed in the topsoils of the studied pedons and to what was reported by [80] that SOC is a major component of soil organic matter (SOM) and a primary source of nitrogen. However, [79] reported that SOM content was not a quantitative indicator of the capacity of soil to supply nitrogen for plant growth even when the soil had more SOM. The timing and amount of nitrogen released from soil organic matter depend on soil temperature, moisture, and many other soil management factors. [59] reported that soils with TN ranging from 0.15 $0.20 \%$ are favourable for cassava production. Therefore, according to [59] only TN of MARU-PI pedon would favour cassava growth and production as opposed to pedons MISSE$\mathrm{P} 1$ and BIHA-P1.

The carbon-nitrogen ratio ( $\mathrm{C}: \mathrm{N}$ ratio) gives an indication of the quality of organic matter present in the soils [7]. The $\mathrm{C}: \mathrm{N}$ ratio of the studied pedons ranged from moderate quality (20) to good quality (10) [42, 53, 5, 37]. The studied pedons had the following C:N ratios: MARU-P1 had good quality ( 8
- 13) C:N ratio throughout the pedon while MISSE-P1 and BIHA-P1 had C:N ratios ranging from good quality (11 - 12) to medium quality $(13-20)$. In all pedons, $\mathrm{C}: \mathrm{N}$ ratios decreased with increasing depth (Table 4). This might be due high SOC in pedons MARU-P1 and BIHA-P1 topsoils and medium SOC in pedon MISSE-P1 topsoil as compared to subsoils of the studied pedons. Generally, the studied pedons had good quality organic matter in the topsoils that signified high decomposition rate by soil microbes leading to nutrients release into the soils $[81,82,66]$.

\subsubsection{Available Phosphorus and Exchangeable Bases}

The available phosphorus (P) (Table 4) of the studied pedons ranged from low $\left(1.48 \mathrm{mg} \mathrm{kg}^{-1}\right)$ to high $\left(41.98 \mathrm{mg} \mathrm{kg}^{-1}\right)$ $[42,78,5,37,79]$. The individual pedons had the following available P levels: Pedons MARU-P1 and BIHA-P1 had P levels ranging from $3.08-6.17 \mathrm{mg} \mathrm{kg}^{-1}$ and from $1.48-6.32$ $\mathrm{mg} \mathrm{kg}^{-1}$ respectively, which signified low available $P$ throughout the pedons, whereas pedon MISSE-P1 had $\mathrm{P}$ levels ranging from low $\left(6.07 \mathrm{mg} \mathrm{kg}^{-1}\right)$ to high $\left(41.98 \mathrm{mg} \mathrm{kg}^{-1}\right)$. In all pedons, available $\mathrm{P}$ decreased with increasing depth (Table 4). Pedon MISSE-P1 had higher content of available P in the topsoil than pedons MARU-P1 and BIHA-P1 which had low levels throughout their profile depths. Some researchers elsewhere $[83,9]$ reported similar trend. The low available $\mathrm{P}$ in pedons MARU-P1 and BIHA-P1 may be attributed to low inherent $P$ in their parent materials which developed mainly on basement rocks of granite, quartzite and shale $[63,30,16]$ and due to the effects of low soil $\mathrm{pH}$ which normally favours $\mathrm{P}$ fixation $[66,16]$. The fixation process involves reaction of $\mathrm{P}$ with iron $(\mathrm{Fe})$ and aluminum $(\mathrm{Al})$ thereby inhibiting availability of $\mathrm{P}$ into the soil for plant uptake [53, 83, 66, 9]. [53] reported that available $\mathrm{P}$ of $<15$ $\mathrm{mg} \mathrm{kg}{ }^{-1}$ in soils would show crop response to $\mathrm{P}$ as observed in pedons MARU-P1 and BIHA-P1. [59] reported that soils with available $P$ ranging from $10-14 \mathrm{mg} \mathrm{kg}^{-1}$ are favourable for cassava production. Therefore, according to [59] only available $\mathrm{P}$ of pedon MISSE-P1 would favour cassava growth and development as opposed to pedons MARU-P1 and BIHA-P1.

The exchangeable bases $\left(\mathrm{Ca}^{2+}, \mathrm{Mg}^{2+}, \mathrm{K}^{+}, \mathrm{Na}^{+}\right)$values (Table 5) of the studied pedons ranged from very low $(0.56$ $\mathrm{mg}$ cmol(+) $\left.\mathrm{kg}^{-1}\right)$ to high $\left(5.80 \mathrm{cmol}(+) \mathrm{kg}^{-1}\right)$ for $\mathrm{Ca}^{2+}$, from very low $\left(0.19 \mathrm{cmol}(+) \mathrm{kg}^{-1}\right)$ to medium $\left(2.10 \mathrm{cmol}(+) \mathrm{kg}^{-1}\right)$ for $\mathrm{Mg}^{2+}$, from very low $\left(0.07 \mathrm{cmol}(+) \mathrm{kg}^{-1}\right)$ to medium $(0.53$ $\left.\operatorname{cmol}(+) \mathrm{kg}^{-1}\right)$ for $\mathrm{K}^{+}$and very low $\left(0.05-0.09 \mathrm{cmol}(+) \mathrm{kg}^{-1}\right)$ throughout the pedons for $\mathrm{Na}^{+}[76,42,77,5,37,78]$. The individual pedons had the following exchangeable bases levels: For calcium $\left(\mathrm{Ca}^{2+}\right)$, MARU-P1 had values ranging from very low $\left(0.56 \mathrm{cmol}(+) \mathrm{kg}^{-1}\right)$ to low $\left(1.78 \mathrm{cmol}(+) \mathrm{kg}^{-1}\right)$, MISSE-P1 from low $\left(1.78 \mathrm{cmol}(+) \mathrm{kg}^{-1}\right)$ to medium $(4.40$ $\left.\mathrm{cmol}(+) \mathrm{kg}^{-1}\right)$ and BIHA-P1 from low $\left(2.70 \mathrm{cmol}(+) \mathrm{kg}^{-1}\right)$ to high $\left(5.80 \mathrm{cmol}(+) \mathrm{kg}^{-1}\right)$. For magnesium $\left(\mathrm{Mg}^{2+}\right)$, MARU-P1 had values ranging from very low $\left(0.19 \mathrm{cmol}(+) \mathrm{kg}^{-1}\right)$ to low $\left(0.44 \mathrm{cmol}(+) \mathrm{kg}^{-1}\right)$, MISSE-P1 from medium $(1.00 \mathrm{cmol}(+)$ $\left.\mathrm{kg}^{-1}\right)$ to high $\left(2.10 \mathrm{cmol}(+) \mathrm{kg}^{-1}\right)$ and BIHA-P1 from low 
(0.77 $\mathrm{mg} \mathrm{kg}^{-1}$ ) to high (2.09 $\mathrm{mg} \mathrm{kg}^{-1}$ ) (Table 5). For potassium $\left(\mathrm{K}^{+}\right)$, MARU-P1 had values ranging from very low $\left(0.12 \mathrm{cmol}(+) \mathrm{kg}^{-1}\right)$ to low $\left(0.18 \mathrm{cmol}(+) \mathrm{kg}^{-1}\right)$, MISSE-P1 from low $\left(0.19 \mathrm{cmol}(+) \mathrm{kg}^{-1}\right)$ to medium $\left(0.53 \mathrm{cmol}(+) \mathrm{kg}^{-1}\right)$ and BIHA-P1 had very low values $\left(0.07-0.11 \mathrm{cmol}(+) \mathrm{kg}^{-1}\right)$ throughout the pedon. For sodium $\left(\mathrm{Na}^{+}\right)$, all studied pedons had very low $\left(0.05-0.09 \mathrm{cmol}(+) \mathrm{kg}^{-1}\right)$ values throughout the pedons. In all studied pedons, exchangeable bases decreased with increasing depth due low organic matter content in subsoils of the studied pedons (Table 4) and due to decreased soil $\mathrm{pH}$ (more acidity) with increasing depths caused by higher $\mathrm{Al}_{2} \mathrm{O}_{3}$ in subsoils than in topsoils. However, soils with low exchangeable bases tend to show plant nutrient imbalances, unavailability and nutrient induced deficiencies [84, 16]. [59] reported that the soils with $\mathrm{Ca}^{2+}, \mathrm{Mg}^{2+}, \mathrm{K}^{+}$and $\mathrm{Na}^{+}$ranging from 1.0 - $5.0 \mathrm{mg} \mathrm{kg}^{-1}, 0.4-1.0 \mathrm{mg} \mathrm{kg}^{-1}, 0.2-0.4 \mathrm{mg} \mathrm{kg}^{-1}$ and $<0.2 \mathrm{mg} \mathrm{kg}^{-1}$, respectively, are fovourable for cassava production. Therefore, according to [59] all exchangeable bases levels in MISSE-P1 are fovourable for cassava production whereas in pedons MARU-P1 and BIHA-P1, only $\mathrm{Ca}^{2+}, \mathrm{Mg}^{2+}$, and $\mathrm{Na}^{+}$are favourable as opposed to $\mathrm{K}^{+}$, which requires the application $\mathrm{K}$ containing fertilizers [68].

\subsubsection{Cation Exchange Capacity (CEC), Exchangeable Sodium Percentage (ESP) and Percentage Base Saturation (\% BS)}

Cation exchange capacity of the soil $\left(\mathrm{CEC}_{\text {soil }}\right)$ plays an important role in soil fertility as high $\mathrm{CEC}_{\text {soil }}$ values reflect high soil fertility [85]. The $\mathrm{CEC}_{\text {soil }}$ of the studied pedons (Table 5) ranged from very low $\left(2.60 \mathrm{cmol}(+) \mathrm{kg}^{-1}\right)$ to high $\left(20.80 \mathrm{cmol}(+) \mathrm{kg}^{-1}\right)[78,5,37,79]$. The individual pedons had the following CEC levels: MARU-P1 had CEC ranging from low $\left(6.40 \mathrm{cmol}(+) \mathrm{kg}^{-1}\right)$ to high $\left(28.80 \mathrm{cmol}(+) \mathrm{kg}^{-1}\right)$ while MISSE-P1 had $\mathrm{CEC}_{\text {soil }}$ ranging from very low $(2.60$ cmol(+) $\left.\mathrm{kg}^{-1}\right)$ to low $\left(11.80 \mathrm{cmol}(+) \mathrm{kg}^{-1}\right)$ and BIHA-P1 had $\mathrm{CEC}_{\text {soil }}$ ranging from low $\left(9.20 \mathrm{cmol}(+) \mathrm{kg}^{-1}\right)$ to medium $\left(14.80 \mathrm{cmol}(+) \mathrm{kg}^{-1}\right)$. In all pedons, $\mathrm{CEC}_{\text {soil }}$ decreased with increasing depth. The topsoil of pedon MARU-P1 had high $\mathrm{CEC}_{\text {soil }}\left(28.80 \mathrm{cmol}(+) \mathrm{kg}^{-1}\right)$ followed by that of BIHA-P1 which had medium $\mathrm{CEC}_{\text {soil }}\left(14.80 \mathrm{cmol}(+) \mathrm{kg}^{-1}\right)$ and the least was that of pedon MISSE-P1 which had low $\mathrm{CEC}_{\text {soil }}(11.80$ cmol $\left.(+) \mathrm{kg}^{-1}\right)$. Other researchers $[6,9,74]$ reported similar trend. The decreased trend of $\mathrm{CEC}_{\text {soil }}$ with increasing depth was attributed to the presence of higher levels of SOM in topsoils than in subsoils [6, 74].

$\mathrm{CEC}_{\text {clay }}$ is an important indicator of the type of clay minerals in a particular soil $[86,16]$. The calculated $\mathrm{CEC}_{\text {clay }}$ values (Table 5) of the studied pedons ranged from very high (92.98 $\left.131.51 \mathrm{cmol}(+) \mathrm{kg}^{-1}\right)$ to low $\left(10.02 \mathrm{cmol}(+) \mathrm{kg}^{-1}\right)$ in pedon MARU-P1, from very high $\left(67.67-70.92 \mathrm{cmol}(+) \mathrm{kg}^{-1}\right)$ to medium (12.01 - $\left.19.00 \mathrm{cmol}(+) \mathrm{kg}^{-1}\right)$ in pedon MISSE-P1 and from high $\left(36.42 \mathrm{cmol}(+) \mathrm{kg}^{-1}\right)$ to medium (18.17 - 24.87 cmol $(+) \mathrm{kg}^{-1}$ ) in pedon BIHA-P1. This implied that subsoils of the studied pedons were more highly weathered than topsoils. The low $\mathrm{CEC}_{\text {clay }}$ in pedon MISSE-P1 was attributed to the coarse texture of the soil. Highly weathered soils with low $\mathrm{CEC}_{\text {clay }}$ values are generally dominated by $1: 1$ silicate clay minerals like kaolinite, dickite, nacrite and halloysite that characterize high degree of weathering $[86,66,16]$.

Table 5. Exchangeable bases, cation exchange capacity exchangeable sodium percentage and base saturation of the studied pedons in Bukoba, Missenyi and Biharamulo Districts, Tanzania.

\begin{tabular}{|c|c|c|c|c|c|c|c|c|c|c|c|c|}
\hline \multirow{2}{*}{ Location } & \multirow{2}{*}{ Pedon } & \multirow{2}{*}{ Horizon } & \multirow{2}{*}{ Depth (cm) } & \multicolumn{4}{|c|}{ Exchangeable bases $\left(\mathrm{cmol}(+) \mathrm{kg}^{-1}\right)$} & \multirow{2}{*}{\multicolumn{2}{|c|}{$\begin{array}{l}\text { TEB CEC } \text { soil } \\
\left(\mathrm{cmol}(+) \mathrm{kg}^{-1}\right)\end{array}$}} & \multirow[t]{2}{*}{$\mathrm{CEC}_{\text {clay }}$} & \multirow{2}{*}{$-\operatorname{ESP}(\%)$} & \multirow{2}{*}{ BS (\%) } \\
\hline & & & & $\mathrm{Ca}^{2+}$ & $\mathrm{Mg}^{2+}$ & $\mathrm{Na}^{+}$ & $\mathbf{K}^{+}$ & & & & & \\
\hline \multirow{5}{*}{ TMRK } & \multirow{5}{*}{$\begin{array}{l}\text { MARU- } \\
\text { P1 }\end{array}$} & Ap & $0-24 / 30$ & $1.78 \mathrm{~L}$ & $0.44 \mathrm{~L}$ & $0.06 \mathrm{VL}$ & $0.18 \mathrm{~L}$ & 2.46 & $28.80 \mathrm{H}$ & $131.51 \mathrm{VH}$ & $0.21 \mathrm{NSD}$ & $8.54 \mathrm{~L}$ \\
\hline & & BAts & $24 / 30-38 / 52$ & $1.78 \mathrm{~L}$ & $0.33 \mathrm{~L}$ & $0.06 \mathrm{VL}$ & $0.13 \mathrm{~L}$ & 2.30 & $27.80 \mathrm{H}$ & $92.98 \mathrm{VH}$ & $0.22 \mathrm{NSD}$ & $8.27 \mathrm{~L}$ \\
\hline & & Bts-1 & $38 / 52-70 / 75$ & $1.78 \mathrm{VL}$ & $0.56 \mathrm{~L}$ & $0.06 \mathrm{VL}$ & $0.15 \mathrm{~L}$ & 2.55 & $13.80 \mathrm{M}$ & $23.43 \mathrm{M}$ & $0.43 \mathrm{NSD}$ & $18.48 \mathrm{~L}$ \\
\hline & & Bts-2 & $70 / 75-115$ & $1.43 \mathrm{VL}$ & $0.40 \mathrm{~L}$ & $0.06 \mathrm{VL}$ & $0.12 \mathrm{VL}$ & 2.01 & $8.40 \mathrm{~L}$ & $13.14 \mathrm{M}$ & $0.71 \mathrm{NSD}$ & $23.93 \mathrm{M}$ \\
\hline & & Bts-3 & $115-200^{+}$ & $0.56 \mathrm{VL}$ & $0.19 \mathrm{VL}$ & $0.05 \mathrm{VL}$ & $0.12 \mathrm{VL}$ & 0.92 & $6.40 \mathrm{~L}$ & $10.02 \mathrm{~L}$ & $0.78 \mathrm{NSD}$ & $24.38 \mathrm{~L}$ \\
\hline \multirow{5}{*}{ MBYP } & \multirow{5}{*}{$\begin{array}{l}\text { MISSE- } \\
\text { P1 }\end{array}$} & Ap & $0-35 / 55$ & $4.40 \mathrm{M}$ & $1.60 \mathrm{M}$ & $0.06 \mathrm{VL}$ & $0.53 \mathrm{M}$ & 6.59 & $11.80 \mathrm{~L}$ & $70.59 \mathrm{VH}$ & $0.50 \mathrm{NSD}$ & $55.85 \mathrm{M}$ \\
\hline & & $\mathrm{Cg}-2$ & $75 / 105-115$ & $3.28 \mathrm{M}$ & $2.01 \mathrm{M}$ & $0.09 \mathrm{VL}$ & $0.20 \mathrm{~L}$ & 5.58 & $6.20 \mathrm{~L}$ & $19.0 \mathrm{M}$ & $1.45 \mathrm{NSD}$ & $90.00 \mathrm{H}$ \\
\hline & & $\mathrm{Cg}-3$ & $115-125$ & $2.28 \mathrm{~L}$ & $1.73 \mathrm{M}$ & $0.06 \mathrm{VL}$ & $0.39 \mathrm{M}$ & 4.46 & $4.60 \mathrm{VL}$ & $17.27 \mathrm{M}$ & $1.30 \mathrm{NSD}$ & $96.96 \mathrm{H}$ \\
\hline & & $\mathrm{Cg}-4$ & $125-138^{+}$ & $2.28 \mathrm{~L}$ & $1.62 \mathrm{M}$ & $0.09 \mathrm{VL}$ & $0.40 \mathrm{M}$ & 4.39 & $4.40 \mathrm{VL}$ & $15.92 \mathrm{M}$ & $2.05 \mathrm{NSD}$ & $99.77 \mathrm{H}$ \\
\hline & & $\mathrm{Cg}-5$ & $138-167$ & $1.78 \mathrm{~L}$ & $1.00 \mathrm{M}$ & $0.08 \mathrm{VL}$ & $0.19 \mathrm{~L}$ & 3.05 & $2.60 \mathrm{VL}$ & $12.01 \mathrm{M}$ & $3.08 \mathrm{NSD}$ & $117.31 \mathrm{H}$ \\
\hline \multirow{4}{*}{ RKRF } & \multirow{4}{*}{ BIHA-P1 } & Ap & $0-17 / 20$ & $5.80 \mathrm{H}$ & $2.09 \mathrm{H}$ & $0.07 \mathrm{VL}$ & $0.11 \mathrm{VL}$ & 8.07 & $14.80 \mathrm{M}$ & $36.42 \mathrm{H}$ & 0.47 NSD & $54.53 \mathrm{M}$ \\
\hline & & BAs & $17 / 20-50$ & $4.93 \mathrm{M}$ & $1.40 \mathrm{M}$ & $0.05 \mathrm{VL}$ & $0.08 \mathrm{VL}$ & 6.46 & $11.60 \mathrm{~L}$ & $24.87 \mathrm{M}$ & $0.43 \mathrm{NSD}$ & $55.69 \mathrm{M}$ \\
\hline & & Bts-1 & $50-90$ & $3.18 \mathrm{M}$ & $0.82 \mathrm{M}$ & $0.06 \mathrm{VL}$ & $0.10 \mathrm{VL}$ & 4.16 & $11.00 \mathrm{~L}$ & $22.16 \mathrm{M}$ & $0.55 \mathrm{NSD}$ & $37.82 \mathrm{M}$ \\
\hline & & Bts-3 & $121-170^{+}$ & $2.70 \mathrm{M}$ & $0.77 \mathrm{~L}$ & $0.05 \mathrm{VL}$ & $0.07 \mathrm{VL}$ & 3.59 & $9.20 \mathrm{~L}$ & $18.17 \mathrm{M}$ & 0.54 NSD & $39.02 \mathrm{M}$ \\
\hline
\end{tabular}

TMRK = TARI Maruku (Tanzania Agricultural Research Institute, Maruku Centre); MBYP = Mabuye Primary School; RKRF = Rukaragata Farmer's Extension Centre; MARU-P1 = Maruku profile 1; MISSE-P1 = Missenyi profile 1; BIHA-P1 = Biharamulo profile 1

Chemical property: $\mathrm{Ca}=$ calcium; $\mathrm{Mg}=$ magnesium; $\mathrm{K}=$ potassium; $\mathrm{Na}=$ sodium; $\mathrm{CEC}=$ cation exchange capacity; $\mathrm{ESP}=$ exchangeable sodium percentage; $\mathrm{BS}=$ base saturation

Rating: $\mathrm{L}=$ low; $\mathrm{VL}=$ very low; $\mathrm{H}=$ high; $\mathrm{VH}=$ very high; $\mathrm{M}=$ medium; $\mathrm{NSD}=$ non sodic $[77,42,53,78,5,37,79]$

Exchangeable sodium percentage (ESP) is the measure of soil sodicity [5]. The ESP of the studied pedons (Table 5) ranged from $0.21-3.08 \%$ throughout the profile depths, which according to $[42,78,5]$, characterize non-sodic soils.
In all studied pedons, ESP increased with depth, which is similar to the trend reported by [6]. This might be due to the non-sodic nature of the parent materials in the study area. However, according to $[42,5]$ soils with ESP $<6 \%$ are non- 
sodic and favourable for growth and production of crops. Therefore, the soils of the studied sites are favourable for cassava growth and development.

Percentage base saturation (BS) of the studied pedons (Table 5) ranged from low (8.54\%) to high (117\%) [53]. The individual pedons had the following BS levels: MARU-P1 had BS ranging from low (8.54\%) to medium (23.93\%) while MISSE-P1 had BS ranging from medium (55.85\% to high (117.31\%) and BIHA-P1 had medium BS (35.43 - 55.69\%) throughout the pedon. Topsoils of MISSE-P1 and BIHA-P1 had medium values whereas topsoil of MARU-P1 had low value. In MARU-P1 and MISSE-P1 pedons, BS increased with depth whereas in BIHA-P1, BS decreased with depth. Similar trend was observed by [74] working on the soils of Meatu District, Tanzania. [32] reported that BS value of $>50 \%$ is high and more favourable for crop production whereas BS value of $<50 \%$ is low and less favourable for crop production. Therefore, according to [32] topsoils of MISSE-P1 and BIHAP1 were favourable for crop production including cassava whereas that of MARU-P1 was less favourable. Low base saturation levels imply acid conditions, which lead to toxicity of cations like aluminum and manganese [53, 2].

\subsubsection{Nutrient Balance of the Studied Pedons}

Nutrient imbalance influences the uptake of nutrients by inducing deficiencies of nutrients present in the soil in good quantities $[87,2]$. Nutrient balance in this study (Table 6) was determined using the ratio of $\mathrm{Ca}: \mathrm{Mg}, \mathrm{Ca}$ TEB, Mg:K and $\%$ (K:TEB). The Ca:Mg levels of the studied pedons were favourable (1.32 - 5.19) throughout the pedons according to $[53,5,2]$, who reported the ratios between $1.2-5.2$ being favourable for crop growth and development. Topsoils of all studied pedons had favourable levels of $\mathrm{Ca}: \mathrm{Mg}$ of 2.75, 2.78 and 4.10 for MISSE-P1, BIHA-P1 and MARU-P1, respectively and all the studied pedons had favourable $\mathrm{Ca}: \mathrm{Mg}$ levels throughout the pedons. Similar results were reported by [74] working on the soils of Meatu District, Tanzania. Presence of higher calcium than magnesium indicates better conditions for crop growth in terms of improved gas exchange, good clay aggregation and structural stability [88, 74]. Nevertheless, [87, 2] reported that unfavourable $\mathrm{Ca}: \mathrm{Mg}$ ratios can lead to nutrient imbalance in the soils which limits the uptake of both $\mathrm{Ca}$ and $\mathrm{Mg}$. Similar results were reported by $[74,9]$ working on the soils of Meatu District and southern Tanzania, respectively.

Table 6. Nutrient balance in the studied pedons in Bukoba, Missenyi and Biharamulo Districts, Tanzania.

\begin{tabular}{|c|c|c|c|c|c|c|c|}
\hline Location & Pedon & Horizon & Depth (cm) & $\mathrm{Ca} / \mathrm{Mg}$ & $\mathrm{Ca} / \mathrm{TEB}$ & $\mathrm{Mg} / \mathrm{K}$ & $\%($ K/TEB $)$ \\
\hline \multirow{4}{*}{ TMRK } & \multirow{4}{*}{ MARU-P1 } & $\mathrm{Ap}$ & $0-24 / 30$ & $4.10 \mathrm{~F}$ & $0.72 \mathrm{NF}$ & $2.44 \mathrm{~F}$ & $7.32 \mathrm{~F}$ \\
\hline & & BAts & $24 / 30-38 / 52$ & $5.19 \mathrm{NF}$ & $0.77 \mathrm{NF}$ & $2.54 \mathrm{~F}$ & $5.65 \mathrm{~F}$ \\
\hline & & Bts-2 & $70 / 75-115$ & $3.58 \mathrm{~F}$ & $0.71 \mathrm{NF}$ & $3.33 \mathrm{~F}$ & $5.97 \mathrm{~F}$ \\
\hline & & Bts-3 & $115-200^{+}$ & $2.95 \mathrm{~F}$ & $0.61 \mathrm{NF}$ & $1.58 \mathrm{~F}$ & $13.04 \mathrm{~F}$ \\
\hline \multirow{5}{*}{ MBYP } & \multirow{5}{*}{ MISSE-P1 } & Ap & $0-35 / 55$ & $2.75 \mathrm{~F}$ & $0.67 \mathrm{NF}$ & $3.02 \mathrm{~F}$ & $8.04 \mathrm{~F}$ \\
\hline & & $\mathrm{Cg}-2$ & $75 / 105-115$ & $1.63 \mathrm{~F}$ & $0.59 \mathrm{NF}$ & $10.05 \mathrm{NF}$ & $3.58 \mathrm{~F}$ \\
\hline & & $\mathrm{Cg}-3$ & $115-125$ & $1.32 \mathrm{~F}$ & $0.51 \mathrm{NF}$ & $4.44 \mathrm{NF}$ & $8.74 \mathrm{~F}$ \\
\hline & & $\mathrm{Cg}-4$ & $125-138^{+}$ & $1.41 \mathrm{~F}$ & $0.52 \mathrm{NF}$ & $4.05 \mathrm{NF}$ & $9.11 \mathrm{~F}$ \\
\hline & & $\mathrm{Cg}-5$ & $138-167$ & $1.78 \mathrm{~F}$ & $0.58 \mathrm{NF}$ & $5.26 \mathrm{NF}$ & $6.23 \mathrm{~F}$ \\
\hline \multirow{4}{*}{ RKRF } & \multirow{4}{*}{ BIHA-P1 } & Ap & $0-17 / 20$ & $2.78 \mathrm{~F}$ & $0.72 \mathrm{NF}$ & $19.00 \mathrm{NF}$ & $1.36 \mathrm{NF}$ \\
\hline & & BAs & $17 / 20-50$ & $3.52 \mathrm{~F}$ & $0.76 \mathrm{NF}$ & $17.50 \mathrm{NF}$ & $1.24 \mathrm{NF}$ \\
\hline & & Bts-2 & $90-121$ & $3.94 \mathrm{~F}$ & $0.76 \mathrm{NF}$ & $7.00 \mathrm{NF}$ & $2.76 \mathrm{~F}$ \\
\hline & & Bts-3 & $121-170^{+}$ & $3.51 \mathrm{~F}$ & $0.75 \mathrm{NF}$ & $11.00 \mathrm{NF}$ & $1.95 \mathrm{NF}$ \\
\hline
\end{tabular}

TMRK = TARI Maruku (Tanzania Agricultural Research Institute, Maruku Centre); MBYP = Mabuye Primary School; RKRF = Rukaragata Farmer's Extension Centre; MARU-P1 = Maruku profile 1; MISSE-P1 = Missenyi profile 1; BIHA-P1 = Biharamulo profile 1

Chemical property: $\mathrm{Ca}=$ calcium; $\mathrm{Mg}=$ magnesium; $\mathrm{K}=$ potassium; $\mathrm{TEB}=$ total exchangeable bases

Rating: $\mathrm{F}=$ favourable, $\mathrm{NF}=$ not favourable $[53,5,1,2]$

The Mg:K levels of the studied pedons (Table 6) ranged from favourable $1.58-3.33)$ to not favourable (4.05 - 19.00) according to $[53,5]$ who reported the ratio between $1-4$ being favourable for crop growth and development. The individual pedons had the following $\mathrm{Mg}: \mathrm{K}$ ratios: In BIHA$\mathrm{P} 1$ and MISSE-P1 pedons, $\mathrm{Mg}: \mathrm{K}$ ratios were not favourable whereas in MARU-P1 they were favourable throughout the pedon. Topsoils of MARU-P1 and MISSE-P1 had favourable $\mathrm{Mg}: \mathrm{K}$ whereas that of BIHA-P1 had unfavourable level. This signified the presence of nutrient imbalance in pedon BIHA$\mathrm{P} 1$, which may cause $\mathrm{Ca}$ - induced deficiency of $\mathrm{K}$ and thus limits $\mathrm{K}$ uptake $[53,87,2]$ due to presence of high Ca levels.
The $\%(\mathrm{~K}: \mathrm{TEB})$ of the studied pedons (Table 6) ranged from not favourable $(1.36-1.95 \%)$ to favourable $(2.40$ $8.04 \%$ ) according to [2] who reported the value above $2 \%$ being favourable for growth and development of most tropical crops. The individual pedons had the following\%(K:TEB) levels: In MARU-P1 and MISSE$\mathrm{P} 1, \%(\mathrm{~K}: \mathrm{TEB})$ were favourable $(3.17-13.04 \%)$ throughout the pedons whereas in BIHA-P1 they ranged from not favourable $(1.24-1.95 \%)$ to favourable $(2.40-2.76 \%)$. Topsoils of MARU-P1 and MISSE-P1 had favourable levels of $7.32 \%$ and $8.04 \%$, respectively, whereas that of BIHA-P1 had unfavourable $(1.36 \%)$ level. This implied that in terms 
of $\%(\mathrm{~K}: \mathrm{TEB})$ ratio, BIHA-P1 pedon was not favourable for production of crops including cassava due to presence of nutrient imbalance, which leads to $\mathrm{K}$ induced deficiency of other bases like $\mathrm{Mg}$ and $\mathrm{Ca}$ [53].

\subsubsection{Micronutrients}

The exchangeable micronutrients $(\mathrm{Cu}, \mathrm{Zn}, \mathrm{Fe}$, and $\mathrm{Mn})$ values of the studied pedons (Table 7) ranged from medium $\left(0.29-1.39 \mathrm{mg} \mathrm{kg}^{-1}\right)$ to high $\left(2.20-3.54 \mathrm{mg} \mathrm{kg}^{-1}\right)$ for $\mathrm{Cu}$, from low $\left(0.22-0.78 \mathrm{mg} \mathrm{kg}^{-1}\right)$ to high $\left(6.61 \mathrm{mg} \mathrm{kg}^{-1}\right)$ for $\mathrm{Zn}$, high $\left(12.76-108 \mathrm{mg} \mathrm{kg}^{-1}\right)$ throughout the pedons for $\mathrm{Fe}$ and from medium $\left(1.48-4.49 \mathrm{mg} \mathrm{kg}^{-1}\right)$ to high $(5.57-74.83 \mathrm{mg}$ $\mathrm{kg}^{-1}$ high for Mn $[89,90,91,92,93]$. The individual pedons had the following micronutrient levels: For copper $(\mathrm{Cu})$, all the studied pedons had medium $\left(0.29-1.39 \mathrm{mg} \mathrm{kg}^{-1}\right)$ to high (2.20 - $3.54 \mathrm{mg} \mathrm{kg}^{-1}$ ) levels. For Zinc (Zn), MARU-P1 had values ranging from low $\left(0.22-0.25 \mathrm{mg} \mathrm{kg}^{-1}\right)$ to medium (0.85 - $\left.1.39 \mathrm{mg} \mathrm{kg}^{-1}\right)$, MISSE-P1 from low $\left(0.68 \mathrm{mg} \mathrm{kg}^{-1}\right)$ to high (6.61 mg kg-1) and BIHA-P1 from low (0.56- $0.78 \mathrm{mg}$ $\left.\mathrm{kg}^{-1}\right)$ to medium $\left(1.28 \mathrm{mg} \mathrm{kg}^{-1}\right)$. For Iron (Fe), all studied pedons had high levels $\left(12.76-108 \mathrm{mg} \mathrm{kg}^{-1}\right)$ throughout the profile depths. For manganese $(\mathrm{Mn})$, all the studied pedons had medium (1.48 - $\left.4.49 \mathrm{mg} \mathrm{kg}^{-1}\right)$ to high $(5.57-74.83 \mathrm{mg}$ $\mathrm{kg}^{-1}$ ) levels, which decreased with increasing depth [94, 95, 96]. Iron (Fe) decreased with increasing soil depth [96] in MARU-P1 and MISSE-P1 but increased with depth in
BIHA-P1 probably due to relatively lower $\mathrm{pH}$ in subsoils than in topsoils [89]. There was no regular trend of $\mathrm{Cu}$ and $\mathrm{Zn}$ in MARU-P1 and MISSE-P1 as opposed to BIHA-P1 where $\mathrm{Cu}$ and $\mathrm{Zn}$ decreased with increasing depth (Table 7).

In MARU-P1, the topsoil had medium (1.39 $\mathrm{mg} \mathrm{kg}^{-1}$ ), medium (1.39 $\left.\mathrm{mg} \mathrm{kg}^{-1}\right)$, high (100.91 $\left.\mathrm{mg} \mathrm{kg}^{-1}\right)$, and high (12.91 $\mathrm{mg} \mathrm{kg}^{-1}$ ) levels of $\mathrm{Cu}, \mathrm{Zn}, \mathrm{Fe}$ and $\mathrm{Mn}$, respectively. In MISSE-P1, the topsoil had medium (1.16 mg kg-1), high (6.61 mg kg $\left.{ }^{-1}\right)$, high $\left(98.21 \mathrm{mg} \mathrm{kg}^{-1}\right)$ and high $\left(74.83 \mathrm{mg} \mathrm{kg}^{-1}\right)$ levels of $\mathrm{Cu}, \mathrm{Zn}, \mathrm{Fe}$ and $\mathrm{Mn}$, respectively. In BIHA-P1, the topsoil had high (3.54 mg kg$\left.{ }^{-1}\right)$, medium $\left(1.28 \mathrm{mg} \mathrm{kg}^{-1}\right)$, high (12.76 mg kg-1) and high, (24.19 mg kg $\left.\mathrm{mg}^{-1}\right)$ levels of $\mathrm{Cu}, \mathrm{Zn}$, $\mathrm{Fe}$ and $\mathrm{Mn}$, respectively. Generally, topsoils had higher levels of micronutrients than subsoils of the studied pedons due to higher organic matter content in topsoils than in subsoils [97]. [59] reported that soils with $\mathrm{Cu}, \mathrm{Zn}, \mathrm{Fe}$ and $\mathrm{Mn}$ at the ranges of $0.30-1.0 \mathrm{mg} \mathrm{kg}^{-1}$ ), $1.0-5.0 \mathrm{mg} \mathrm{kg}-1,10.0-100.0$ $\mathrm{mg} \mathrm{kg}^{-1}$ and $10.0-100.0 \mathrm{mg} \mathrm{kg}^{-1}$, respectively, are favourable for cassava production. Therefore, according to [59], $\mathrm{Cu}$ levels in MARU-P1 and BIHA-P1 are not favourable for cassava production whereas in MISSE-P1, $\mathrm{Cu}$ and $\mathrm{Zn}$ were not favourable, implying that for optimum and sustainable production (root yields) of cassava, there should be proper management of $\mathrm{Cu}$ and $\mathrm{Zn}$, such as limited use of $\mathrm{Zn}$ and $\mathrm{Cu}-$ based fungicides [95] in the study area.

Table 7. Micronutrient contents of the studied pedons in Bukoba, Missenyi and Biharamulo Districts, Tanzania.

\begin{tabular}{|c|c|c|c|c|c|c|c|}
\hline \multirow{2}{*}{ Location } & \multirow{2}{*}{ Pedon } & \multirow{2}{*}{ Horizon } & \multirow{2}{*}{ Depth (cm) } & \multicolumn{4}{|c|}{ Micronutrients $\left(\mathrm{mg} \mathrm{kg}^{-1}\right)$} \\
\hline & & & & $\mathrm{Cu}$ & Zn & $\mathrm{Fe}$ & Mn \\
\hline \multirow{5}{*}{ TMRK } & \multirow{5}{*}{ MARU-P1 } & $\mathrm{Ap}$ & $0-24 / 30$ & $1.39 \mathrm{M}$ & $1.39 \mathrm{M}$ & $100.01 \mathrm{H}$ & $12.91 \mathrm{H}$ \\
\hline & & BAts & $24 / 30-38 / 52$ & $1.24 \mathrm{M}$ & $0.85 \mathrm{M}$ & $88.08 \mathrm{H}$ & $6.60 \mathrm{H}$ \\
\hline & & Bts-1 & $38 / 52-70 / 75$ & $3.10 \mathrm{H}$ & $0.22 \mathrm{~L}$ & $90.02 \mathrm{H}$ & $5.57 \mathrm{H}$ \\
\hline & & Bts-2 & $70 / 75-115$ & $2.31 \mathrm{H}$ & $0.25 \mathrm{~L}$ & $78.52 \mathrm{H}$ & $4.98 \mathrm{M}$ \\
\hline & & Bts-3 & $115-200^{+}$ & $1.14 \mathrm{M}$ & $0.85 \mathrm{M}$ & $65.01 \mathrm{H}$ & $4.01 \mathrm{M}$ \\
\hline \multirow{6}{*}{ MBYP } & \multirow{6}{*}{ MISSE-P1 } & Ap & $0-35 / 55$ & $1.16 \mathrm{M}$ & $6.61 \mathrm{H}$ & $98.21 \mathrm{H}$ & $74.83 \mathrm{H}$ \\
\hline & & $\mathrm{Cg}-1$ & $35 / 55-75 / 105$ & $0.51 \mathrm{M}$ & $0.68 \mathrm{~L}$ & $46.89 \mathrm{H}$ & $26.08 \mathrm{H}$ \\
\hline & & $\mathrm{Cg}-2$ & $75 / 105-115$ & $2.65 \mathrm{H}$ & $2.00 \mathrm{M}$ & $46.48 \mathrm{H}$ & $22.74 \mathrm{H}$ \\
\hline & & $\mathrm{Cg}-3$ & $115-125$ & $1.23 \mathrm{M}$ & $0.97 \mathrm{M}$ & $39.25 \mathrm{H}$ & $4.48 \mathrm{M}$ \\
\hline & & $\mathrm{Cg}-4$ & $125-138^{+}$ & $2.28 \mathrm{H}$ & $1.99 \mathrm{M}$ & $46.72 \mathrm{H}$ & $6.92 \mathrm{H}$ \\
\hline & & $\mathrm{Cg}-5$ & $138-167$ & $0.49 \mathrm{M}$ & $0.93 \mathrm{M}$ & $43.73 \mathrm{H}$ & $1.48 \mathrm{M}$ \\
\hline \multirow{5}{*}{ RKRF } & \multirow{5}{*}{ BIHA-P1 } & Ap & $0-17 / 20$ & $3.54 \mathrm{H}$ & $1.28 \mathrm{M}$ & $12.76 \mathrm{H}$ & $24.19 \mathrm{H}$ \\
\hline & & BAs & $17 / 20-50$ & $2.20 \mathrm{H}$ & $0.78 \mathrm{~L}$ & $37.21 \mathrm{H}$ & $28.36 \mathrm{H}$ \\
\hline & & Bts-1 & $50-90$ & $1.27 \mathrm{M}$ & $0.63 \mathrm{~L}$ & $38.33 \mathrm{H}$ & $9.03 \mathrm{H}$ \\
\hline & & Bts-2 & $90-121$ & $0.87 \mathrm{M}$ & $0.69 \mathrm{~L}$ & $39.50 \mathrm{H}$ & $1.59 \mathrm{M}$ \\
\hline & & Bts-3 & $121-170^{+}$ & $0.29 \mathrm{M}$ & $0.56 \mathrm{~L}$ & $45.67 \mathrm{H}$ & $2.26 \mathrm{M}$ \\
\hline
\end{tabular}

TMRK = TARI Maruku (Tanzania Agricultural Research Institute, Maruku Centre); MBYP = Mabuye Primary School; RKRF = Rukaragata Farmer's Extension Centre; MARU-P1 = Maruku profile 1; MISSE-P1 = Missenyi profile 1; BIHA-P1 = Biharamulo profile 1

Micronutrient: $\mathrm{Zn}=$ zinc, $\mathrm{Fe}=$ iron, $\mathrm{Mn}=$ manganese, $\mathrm{Cu}=$ copper

Rating: $\mathrm{L}=$ low, $\mathrm{M}=$ medium, $\mathrm{H}=$ high $[89,90,91,92,93]$

\subsubsection{Total Elemental Composition of the Studied Pedons}

The total soil elemental composition is useful for characterizing soils in relation to soil forming factors and inherent soil properties and is linked to the concentration of the total elements in the soil and the degree of weathering of the parent rock [98]. Some of the elemental oxides analyzed in this study are presented in Table 8 . The amount of $\mathrm{SiO}_{2}$ in the studied pedons ranged from $33.05-33.80 \%$ in MARU-
$\mathrm{P} 1$, from $66.20-88.50 \%$ in MISSE-P1 and from 57.20 $64.00 \%$ in BIHA-P1. In all studied pedons, $\mathrm{SiO}_{2}$ decreased with depth, indicating the presence of more $\mathrm{SiO}_{2}$ in topsoils than in e subsoils and was higher in pedon MISSE-P1 than in pedons MARU-P1 and BIHA-P1 with the order of MISSE$\mathrm{P} 1>$ BIHA-P1 $>$ MARU-P1. The amount of $\mathrm{Al}_{2} \mathrm{O}_{3}$ ranged from $15.00-19.00 \%$ in MARU-P1, from $10.00-13.00 \%$ in MISSE-P1 and from $15.00-20.00 \%$ in BIHA-P1. In all 
studied pedons, $\mathrm{Al}_{2} \mathrm{O}_{3}$ increased with increasing depth, indicating the presence of more $\mathrm{Al}_{2} \mathrm{O}_{3}$ in subsoils than in topsoils and was higher in pedon BIHA-P1 than in pedons MARU-P1 and BIHA-P1 with the order of BIHA-P1 > MARU-P1 > MISSE-P1. The amount of $\mathrm{Fe}_{2} \mathrm{O}_{3}$ ranged from 41.18 - 41.95\% in MARU-P1, from $4.02-5.28 \%$ in MISSE$\mathrm{P} 1$ and from $13.80-16.70 \%$ in BIHA-P1. In pedons MARU$\mathrm{P} 1$ and BIHA-P1, $\mathrm{Fe}_{2} \mathrm{O}_{3}$ increased with depth, indicating the presence of more $\mathrm{Fe}_{2} \mathrm{O}_{3}$ in subsoils than in topsoils. However, there was no regular trend throughout pedon MISSE-P1 indicating the deposition of surface soil materials in subsoils, though more $\mathrm{Fe}_{2} \mathrm{O}_{3}$ was in subsoils than in topsoils. Pedon MARU-P1 had higher $\mathrm{Fe}_{2} \mathrm{O}_{3}$ than pedons MISSE-P1 and BIHA-P1 with the order of MARU-P1 > BIHA-P1 > MISSE-P1. The amount of $\mathrm{K}_{2} \mathrm{O}$ ranged from $0.38-0.42 \%$ in MARU-P1, from $1.93-2.59 \%$ in MISSE-P1 and from $0.50-0.51 \%$ in BIHA-P1. In all studied pedons, $\mathrm{K}_{2} \mathrm{O}$ decreased with increasing depth, indicating the presence of more $\mathrm{K}_{2} \mathrm{O}$ in topsoils than in subsoils and was higher in pedon MISSE-P1 than in pedons BIHA-P1 and MARU-P1 with the order of MISSE-P1 > BIHA-P1 > MARU-P1. The amount of $\mathrm{CaO}$ ranged from $0.31-0.51 \%$ in MARU-P1, from $0.63-1.17 \%$ in MISSE-P1 and from $0.44-0.83 \%$ in BIHA-P1. In all studied pedons, $\mathrm{CaO}$ decreased with increasing depth, indicating the presence of more $\mathrm{CaO}$ in topsoils than in subsoils and was higher in pedon MISSE-P1 than in pedons BIHA-P1 and MARU-P1 with the order of MISSE-P1 > BIHA-P1 > MARU-P1. The amount of $\mathrm{TiO}_{2}$ ranged from $4.23-4.39 \%$ in MARU-P1, from $2.71-2.73 \%$ in MISSE-P1 and from $3.91-4.20 \%$ in BIHA-P1. In all studied pedons, $\mathrm{TiO}_{2}$ increased with depth, indicating the presence of more $\mathrm{TiO}_{2}$ in subsoils than in topsoils and was higher in pedon MARU-P1 than in pedons BIHA-P1 and MISSE-P1 with the order of MARU-P1 > BIHA-P1 > MISSE-P1. The amount of MnO ranged from $0.15-0.24 \%$ in MARU-P1, from $0.06-0.25 \%$ in MISSE-P1 and from 0.07 $0.13 \%$ in BIHA-P1. In all studied pedons, $\mathrm{MnO}$ decreased with increasing depth, indicating the presence of more $\mathrm{MnO}$ in topsoils than in subsoils and was higher in pedon BIHA-P1 than in pedons MARU-P1 and MISSE-P1 with the order of BIHA-P1 > MARU-P1 > MISSE-P1. The amount of MgO ranged from $0.02-0.85 \%$ in MARU-P1, from $0.05-0.37 \%$ in MISSE-P1 and $0.06 \%$ throughout BIHA-P1 horizons. In all studied pedons, $\mathrm{MgO}$ increased with depth, indicating the presence of more $\mathrm{MgO}$ in subsoils than in topsoils and was higher in pedon MARU-P1 than in pedons MISSE-P1 and BIHA-P1 with the order of MARU-P1 > MISSE-P1 > BIHA$\mathrm{P} 1$. The amount of $\mathrm{P}_{2} \mathrm{O}_{5}$ ranged from $7.22-14.54 \%$ in MARU-P1, from $13.91-66.19 \%$ in MISSE-P1 and from $3.39-14.48 \%$ in BIHA-P1. In all studied pedons, $\mathrm{P}_{2} \mathrm{O}_{5}$ decreased with increasing depth, indicating the presence of more $\mathrm{P}_{2} \mathrm{O}_{5}$ in topsoils than in subsoils and was higher in pedon MISSE-P1 than in pedons MARU-P1 and BIHA-P1 with the order of MISSE-P1 > MARU-P1 > BIHA-P1. The amount of $\mathrm{Na}_{2} \mathrm{O}$ ranged from $0.01-0.04 \%$ in MARU-P1, from $0.01-0.65 \%$ in MISSE-P1 and from $0.01-0.03 \%$ in BIHA-P1. In all studied pedons, $\mathrm{Na}_{2} \mathrm{O}$ decreased with depth, indicating the presence of more $\mathrm{Na}_{2} \mathrm{O}$ in topsoils than in subsoils and was higher in MISSE-P1 than in pedons MARU-P1 and BIHA-P1 with the order of MISSE-P1 > MARU-P1 > BIHA-P1.

Table 8. Total elemental composition of the studied pedons in Bukoba, Missenyi and Biharamulo Districts, Tanzania.

\begin{tabular}{|c|c|c|c|c|c|c|c|c|c|c|c|c|c|}
\hline \multirow{2}{*}{ Location } & \multirow{2}{*}{ Pedon } & \multirow{2}{*}{ Horizon } & \multirow{2}{*}{ Depth (cm) } & \multicolumn{10}{|c|}{ Total elemental composition (\%) } \\
\hline & & & & $\mathrm{SiO}_{2}$ & $\mathrm{Al}_{2} \mathrm{O}_{3}$ & $\mathrm{Fe}_{2} \mathrm{O}_{3}$ & $\mathrm{~K}_{2} \mathrm{O}$ & $\mathrm{CaO}$ & $\mathrm{TiO}_{2}$ & MnO & MgO & $\mathrm{P}_{2} \mathrm{O}_{5}$ & $\mathrm{Na}_{2} \mathrm{O}$ \\
\hline \multirow{3}{*}{ TMRK } & \multirow{3}{*}{ MARU-P1 } & Ap & $0-24 / 30$ & 33.80 & 15.00 & 41.18 & 0.42 & 0.51 & 4.23 & 0.24 & 0.02 & 14.54 & 0.04 \\
\hline & & BAts & $24 / 30-38 / 52$ & 33.10 & 16.00 & 41.95 & 0.39 & 0.34 & 4.38 & 0.23 & 0.27 & 9.05 & 0.02 \\
\hline & & Bts-2 & $70 / 75-115$ & 33.05 & 19.00 & 41.95 & 0.38 & 0.31 & 4.39 & 0.15 & 0.85 & 7.22 & 0.01 \\
\hline \multirow{3}{*}{ MBYP } & \multirow{3}{*}{ MISSE-P1 } & Ap & $0-35 / 55$ & 88.50 & 10.00 & 4.02 & 2.59 & 1.17 & 2.71 & 0.25 & 0.05 & 66.19 & 0.65 \\
\hline & & $\mathrm{Cg}-2$ & $75 / 105-115$ & 66.60 & 13.00 & 12.40 & 2.00 & 0.90 & 2.75 & 0.07 & 0.34 & 16.91 & 0.02 \\
\hline & & $\mathrm{Cg}-5$ & $138-167^{+}$ & 66.20 & 13.00 & 5.28 & 1.93 & 0.63 & 2.73 & 0.06 & 0.37 & 13.91 & 0.01 \\
\hline \multirow{3}{*}{ RKRF } & \multirow{3}{*}{ BIHA-P1 } & Ap & $0-17 / 20$ & 64.00 & 15.00 & 13.80 & 0.51 & 0.83 & 3.91 & 0.13 & 0.06 & 14.48 & 0.03 \\
\hline & & BAs & $17 / 20-50$ & 58.70 & 17.00 & 16.40 & 0.50 & 0.65 & 4.23 & 0.10 & 0.06 & 7.77 & 0.01 \\
\hline & & Bts-2 & $90-121$ & 57.20 & 20.00 & 16.70 & 0.50 & 0.44 & 4.23 & 0.07 & 0.06 & 3.39 & 0.01 \\
\hline
\end{tabular}

TMRK = TARI Maruku (Tanzania Agricultural Research Institute, Maruku Centre); MBYP = Mabuye Primary School; RKRF = Rukaragata Farmer's Extension Centre; MARU-P1 = Maruku profile 1; MISSE-P1 = Missenyi profile 1; BIHA-P1 = Biharamulo profile 1.

Generally, the total elemental composition of the studied pedons follows the following orders:

MARU-P1: $\mathrm{Fe}_{2} \mathrm{O}_{3}>\mathrm{SiO}_{2}>\mathrm{Al}_{2} \mathrm{O}_{3}>\mathrm{P}_{2} \mathrm{O}_{5}>\mathrm{TiO}_{2}>\mathrm{CaO}>$ $\mathrm{K}_{2} \mathrm{O}>\mathrm{MnO}>\mathrm{MgO}>\mathrm{Na}_{2} \mathrm{O}$

MISSE-P1: $\mathrm{SiO}_{2}>\mathrm{P}_{2} \mathrm{O}_{5}>\mathrm{Al}_{2} \mathrm{O}_{3}>\mathrm{Fe}_{2} \mathrm{O}_{3}>\mathrm{TiO}_{2}>\mathrm{K}_{2} \mathrm{O}>$ $\mathrm{CaO}>\mathrm{MnO}>\mathrm{MgO}>\mathrm{Na}_{2} \mathrm{O}$

BIHA-P1: $\mathrm{SiO}_{2}>\mathrm{Al}_{2} \mathrm{O}_{3}>\mathrm{Fe}_{2} \mathrm{O}>\mathrm{P}_{2} \mathrm{O}_{5}>\mathrm{TiO}_{2}>\mathrm{CaO}>$ $\mathrm{K}_{2} \mathrm{O}>\mathrm{MnO}>\mathrm{MgO}>\mathrm{Na}_{2} \mathrm{O}$

In all studied pedons, the most abundant oxides were $\mathrm{SiO}_{2}$, $\mathrm{Al}_{2} \mathrm{O}_{3}, \mathrm{Fe}_{2} \mathrm{O}_{3}$, and $\mathrm{P}_{2} \mathrm{O}_{5}$ indicating the presence of high levels of $\mathrm{Si}, \mathrm{Al}, \mathrm{Fe}$ and $\mathrm{P}$ elements in the soils. Other researcher [63,
29, 30] reported that the geology of the study area is dominated by Precambrian rocks of Karagwe-Ankolean system and Bukoban system whereas Bukoban system came after the erosion of Karagwe-Ankolean system. The parent materials of the two systems are shales and quartzite, which are aluminous, siliceous and ferruginous with low magnesium content $[63,30]$. In all studied pedons, the dominant oxide was $\mathrm{SiO}_{2}$ indicating that quartzite is the dominant parent rock in the studied pedons. The high amount of sesquioxides in the studied pedons particularly pedons MARU-P1 and BIHA-P1 signified highly weathered 
conditions [99, 72]. Based on the levels of sesquioxides (oxides of $\mathrm{Al}$ and $\mathrm{Fe}$ ) (Table 8), it is apparent that the soil of MARU-P1 was more weathered than that of pedons BIHAP1 and MISSE-P1 with the order of MARU-P1 > BIHA-P1 > MISSE-P1. The increasing levels of $\mathrm{Al}_{2} \mathrm{O}_{3}$ and $\mathrm{Fe}_{2} \mathrm{O}$ with depth and the decreasing contents of $\mathrm{P}_{2} \mathrm{O}_{5}, \mathrm{CaO}$ and $\mathrm{K}_{2} \mathrm{O}$ with increasing depth is attributed to the decreasing soil $\mathrm{pH}$ with increasing depth observed in the studied pedons as in soils with $\mathrm{pH}<5.5$ there is likelihood of dissolution of aluminum and iron which precipitates with phosphorus leading to P-fixation $[66,16]$. In addition, presence of high rainfall (up to $>2500 \mathrm{~mm}$ ) in the study area might have led to the leaching of $\mathrm{Al}, \mathrm{Fe}$ and other essential plant nutrients like N, P and K [100, 101]. In all studied pedons the amount of all basic oxides were very low due to the nature of parent rocks being dominated by quartzite and shale, which contain more $\mathrm{Si}, \mathrm{Al}$ and $\mathrm{Fe}[63,30]$.

\subsubsection{Weathering Indices of the Studied Pedons}

The kind and arrangement of the horizons and weathering potential are determinants of weathering state of a particular soil [102]. Weathering index is the measure of intensity of chemical weathering by comparing the mineral or compound that is relatively stable and the one that is readily removed by weathering $[102,103]$. The weathering indices presented in this study (Table 9) are $\mathrm{SiO}_{2} / \mathrm{Al}_{2} \mathrm{O}_{3}, \mathrm{SiO}_{2} /\left(\mathrm{Fe}_{2} \mathrm{O}_{3}+\mathrm{Al}_{2} \mathrm{O}_{3}\right)$ and Chemical Index of Alteration $(\mathrm{CIA})=\left[\mathrm{Al}_{2} \mathrm{O}_{3} /\left(\mathrm{Al}_{2} \mathrm{O}_{3}+\mathrm{K}_{2} \mathrm{O}\right.\right.$ $\left.\left.+\mathrm{Na}_{2} \mathrm{O}+\mathrm{CaO}\right)\right] \times 100$. The level of $\mathrm{SiO}_{2} / \mathrm{Al}_{2} \mathrm{O}_{3}$ ranged from 1.74 - 2.25 in MARU-P1, from $5.12-8.85$ in MISSE-P1 and from 2.86 - 4.27 in BIHA-P1 (Table 9). In all studied pedons, $\mathrm{SiO}_{2} / \mathrm{Al}_{2} \mathrm{O}_{3}$ decreased with increasing depth, indicating higher level of $\mathrm{SiO}_{2} / \mathrm{Al}_{2} \mathrm{O}_{3}$ in topsoils than in subsoils, which signified more weathering in subsoils than in topsoils. Other researchers [104, 72] reported similar trend. Moreover, $\mathrm{SiO}_{2} / \mathrm{Al}_{2} \mathrm{O}_{3}$ was higher in pedon MISSE-P1 than in pedons BIHA-P1 and MISSE-P1 with the order of MISSE-P1 >
BIHA-P1 > MARU-P1. However, [104, 72] reported that high values of $\mathrm{SiO}_{2} / \mathrm{Al}_{2} \mathrm{O}_{3}$ indicate low potential for weathering. Therefore, based on the $\mathrm{SiO}_{2} / \mathrm{Al}_{2} \mathrm{O}_{3}$ levels, the order of weathering potential of the studied pedons was MARU-P1 > BIHA-P1 > MISSE-P1. The level of $\mathrm{SiO}_{2} /\left(\mathrm{Fe}_{2} \mathrm{O}_{3}+\mathrm{Al}_{2} \mathrm{O}_{3}\right)$ ranged from $0.54-0.60$ in MARU-P1, from 2.62 - 8.31 in MISSE-P1 and from 1.56 - 2.22 in BIHAP1. In all studied pedons, $\mathrm{SiO}_{2} /\left(\mathrm{Fe}_{2} \mathrm{O}_{3}+\mathrm{Al}_{2} \mathrm{O}_{3}\right)$ decreased with depth, indicating high level of $\mathrm{SiO}_{2} /\left(\mathrm{Fe}_{2} \mathrm{O}_{3}+\mathrm{Al}_{2} \mathrm{O}_{3}\right)$ in topsoils than in subsoils, which signified more weathering in subsoils than in topsoils [72] and was higher in MISSE-P1 than in the other two pedons with the order of MISSE-P1 > BIHA-P1 > MARU-P1. Therefore, based on the levels of $\mathrm{SiO}_{2} /\left(\mathrm{Fe}_{2} \mathrm{O}_{3}+\mathrm{Al}_{2} \mathrm{O}_{3}\right)$, the order of weathering potential of the studied pedons was MARU-P1 > BIHA-P1 > MISSE-P1.

The CIA is a quantitative indicator of the degree of weathering of silicates. Feldspars are the most abundant reactive minerals in the earth's crust and once subjected to weathering process they release calcium, sodium, potassium and aluminum into the soils and the proportion of alumina to alkalis would typically increase in the weathered product $[105,8]$. Therefore, high level of CIA indicates high degree of weathering [105]. The CIA in the studied pedons ranged from 93.03 - 96.45\% in MARU-P1, from 69.40 - 82.36\% in MISSE-P1 and from $91.63 \%-95.47 \%$ in BIHA-P1. In all studied pedons, CIA increased with depth, which signified high level of CIA in subsoils than in topsoils and thus more weathering in subsoils than in topsoils. Among the studied pedons, the degree of weathering was higher in pedon MARU-P1 than in pedons BIHA-P1 and MISSE-P1 with the order of MARU-P1 > BIHA-P1 > MISSE-P1. Generally, based on the three weathering indices presented in this study, MARU-P1 was highly weathered followed by BIHA-P1 and the least was MISSE-P1.

Table 9. Weatherability of the studied pedons in Bukoba Rural, Missenyi and Biharamulo Districts, Tanzania.

\begin{tabular}{|c|c|c|c|c|c|c|}
\hline Location & Pedon & Horizon & Depth (cm) & $\mathrm{SiO}_{2} / \mathrm{Al}_{2} \mathbf{O}_{3}$ & $\mathrm{SiO}_{2} /\left(\mathrm{Fe}_{2} \mathrm{O}_{3}+\mathrm{Al}_{2} \mathrm{O}_{3}\right)$ & CIA (\%) \\
\hline \multirow{3}{*}{ TMRK } & \multirow{3}{*}{ MARU-P1 } & Ap & $0-24 / 30$ & 2.25 & 0.60 & 93.93 \\
\hline & & BAts & $24 / 30-38 / 52$ & 2.07 & 0.57 & 95.52 \\
\hline & & Bts-2 & $70 / 75-115$ & 1.74 & 0.54 & 96.45 \\
\hline \multirow{3}{*}{ MBYP } & \multirow{3}{*}{ MISSE-P1 } & Ap & $0-35 / 55$ & 8.85 & 6.31 & 69.40 \\
\hline & & $\mathrm{Cg}-2$ & $75 / 105-115$ & 5.52 & 3.83 & 81.66 \\
\hline & & $\mathrm{Cg}-5$ & $138-167^{+}$ & 5.12 & 2.62 & 82.36 \\
\hline \multirow{3}{*}{ RKRF } & \multirow{3}{*}{ BIHA-P1 } & Ap & $0-17 / 20$ & 4.27 & 2.22 & 91.63 \\
\hline & & BAs & $17 / 20-50$ & 3.45 & 1.76 & 93.61 \\
\hline & & Bts-2 & $90-121$ & 2.86 & 1.56 & 95.47 \\
\hline
\end{tabular}

TMRK $=$ TARI Maruku (Tanzania Agricultural Research Institute, Maruku Centre); MBYP = Mabuye Primary School; RKRF $=$ Rukaragata Farmer's Extension Centre; MARU-P1 = Maruku profile 1; MISSE-P1 = Missenyi profile 1; BIHA-P1 = Biharamulo profile 1; CIA $=$ Chemical index of alteration $=$ $\left[\mathrm{Al}_{2} \mathrm{O}_{3} /\left(\mathrm{Al}_{2} \mathrm{O}_{3}+\mathrm{K}_{2} \mathrm{O}+\mathrm{Na}_{2} \mathrm{O}+\mathrm{CaO}\right)\right] \times 100$

\subsection{Classification of the Soils of the Study Area}

Field description of soil morphological features and laboratory analytical data (physical and chemical properties) were used to classify the soils of the study areas according to the USDA Soil Taxonomy [41] and the World Reference Base for Soil Resources [56]. Soil diagnostic horizons, properties and materials/features used in classifying the soils and the soil names according to the USDA Soil Taxonomy and the FAO World Reference Base for Soil Resources are presented in Table 10 and Table 11, respectively. According to the USDA Soil Taxonomy, the soils of the studied sites are "Almost flat to 
gently undulating, very deep, clayey, kaolinitic, strongly to very strongly acid, isohyperthemic, Typic Kandiudults" (pedon MARU-P1), "Almost flat, very deep, sandy loam to sandy clay loam, mixed, medium to strongly acid, isohyperthemic, Typic Endoaquolls" (pedon MISSE-P1) and "Almost flat to gently undulating, very deep, clayey, kaolinitic, medium to strongly acid, isohyperthemic, Typic Kandiudults" (pedon BIHA-P1)
(Table 10). Moreover, according to FAO World Reference Base for Soil Resources, the soils of the studied sites are "Haplic Ferralic Acrisols (Clayic, Cutanic, Hyperdystric, Humic, Profondic)" (pedon MARU-P1, "Fluvic Gleyic Phaeozems (Loamic)" (pedon MISSE-P1) and "Chromic Ferralic Acrisols (Clayic, Cutanic, Hyperdystric, Ochric, Profondic)" (pedon MISSE-P1) (Table 11).

Table 10. Diagnostic features and classification of the studied pedons in Bukoba Rural, Missenyi and Biharamulo Districts, Tanzania, according to USDA Soil Taxonomy [41].

\begin{tabular}{|c|c|c|c|c|c|c|c|}
\hline Pedon & $\begin{array}{l}\text { Diagnostic } \\
\text { horizon(s) }\end{array}$ & Other diagnostic features & Order & Suborder & $\begin{array}{l}\text { Great } \\
\text { group }\end{array}$ & Subgroup & Family \\
\hline MARU-P1 & $\begin{array}{l}\text { Umbric } \\
\text { epipedon, } \\
\text { Kandic } \\
\text { horizon }\end{array}$ & $\begin{array}{l}\text { Almost flat to gently undulating, } \\
\text { very deep, sandy clay loam to } \\
\text { clay, kaolinitic, very strong acid to } \\
\text { strong acid, udic SMR, } \\
\text { isohyperthemic STR }\end{array}$ & Ultisols & Udults & Kandiudults & $\begin{array}{l}\text { Typic } \\
\text { Kandiudults }\end{array}$ & $\begin{array}{l}\text { Almost flat to gently undulating, } \\
\text { very deep, clayey, kaolinitic, } \\
\text { strongly to very strongly acid,, } \\
\text { isohyperthemic, Typic Kandiudults }\end{array}$ \\
\hline MISSE-P1 & $\begin{array}{l}\text { Mollic } \\
\text { epipedon }\end{array}$ & $\begin{array}{l}\text { Almost flat, very deep, sandy } \\
\text { loamy to sandy clay loam, mixed, } \\
\text { moderate acid to strong acid, aquic } \\
\text { SMR, isohyperthemic STR, } \\
\text { stratification }\end{array}$ & Mollisols & Aquolls & Endoaquolls & $\begin{array}{l}\text { Typic } \\
\text { Endoaquolls }\end{array}$ & $\begin{array}{l}\text { Almost flat, very deep, sandy loam } \\
\text { to sandy clay loam, mixed, } \\
\text { medium to strongly acid, } \\
\text { isohyperthemic, Typic } \\
\text { Endoaquolls }\end{array}$ \\
\hline BIHA-P1 & $\begin{array}{l}\text { Ochric } \\
\text { epipedon; } \\
\text { Kandic } \\
\text { horizon }\end{array}$ & $\begin{array}{l}\text { Almost flat to gently undulating, } \\
\text { very deep, sandy clay, kaolinitic, } \\
\text { medium to strongly acid, udic } \\
\text { SMR, isohyperthemic STR }\end{array}$ & Ultisols & Udults & Kandiudults & $\begin{array}{l}\text { Typic } \\
\text { Kandiudults }\end{array}$ & $\begin{array}{l}\text { Almost flat to gently undulating, } \\
\text { very deep, clayey, kaolinitic, } \\
\text { medium to strongly acid, } \\
\text { isohyperthemic, Typic Kandiudults }\end{array}$ \\
\hline
\end{tabular}

MARU-P1 = Maruku profile 1; MISSE-P1 = Missenyi profile 1; BIHA-P1 = Biharamulo profile 1; SMR = Soil moisture regime, STR = Soil temperature regime

Table 11. Diagnostic horizons and features, and classification of the studied pedons in Bukoba Rural, Missenyi and Biharamulo Districts, Tanzania, according to WRB for Soil Resources [56].

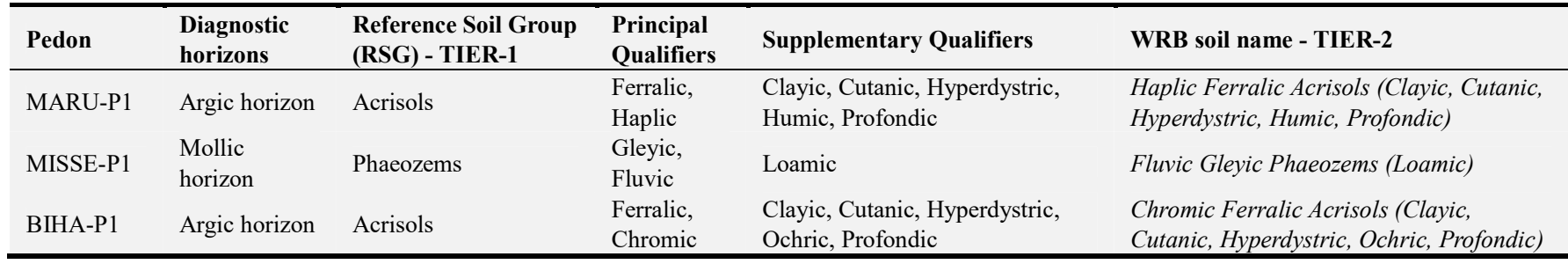

MARU-P1 = Maruku profile 1; MISSE-P1 = Missenyi profile 1; BIHA-P1 = Biharamulo profile 1

\subsection{Suitability Assessment for Cassava Production}

Suitability of the studied pedons for cassava production was assessed based on the observed land/soil characteristics of the respective pedon that were compared to the requirements for cassava crops $[106,59,60,61]$ using simple limiting method $[57,58]$. Data on suitability assessment based on ecological requirements of cassava and actual field conditions of the studied pedons are presented in Table 12. MARU-P1 pedon was moderately suitable due to fertility problem caused by low available phosphorus and exchangeable potassium whereas MISSE-P1 pedon was marginally suitable due to fertility problem caused by very low organic carbon and BIHA-P1 was marginally suitable due to fertility problem caused by very low exchangeable potassium.

Table 12. Suitability assessment based on ecological requirement of cassava and actual field conditions of the studied pedons in Bukoba Rural, Missenyi and Biharamulo Districts, Tanzania.

\begin{tabular}{|c|c|c|c|c|c|c|c|c|}
\hline \multirow{2}{*}{ Land quality } & \multirow{2}{*}{ Diagnostic factor } & \multirow{2}{*}{ Required range } & \multicolumn{3}{|c|}{ Actual field range } & \multicolumn{3}{|l|}{ Rating } \\
\hline & & & MARU-P1 & MISSE-P1 & BIHA-P1 & MARU-P1 & MISSE-P1 & BIHA-P1 \\
\hline \multirow[t]{2}{*}{ Climate (c) } & Annual rainfall (mm) & $500-3000$ & $900-$ & $700-120$ & $600-100$ & $\mathrm{~S} 1$ & $\mathrm{~S} 1$ & $\mathrm{~S} 1$ \\
\hline & Temperature $\left({ }^{\circ} \mathrm{C}\right)$ & $18-30$ & $22-26$ & $22-26$ & $21-28$ & $\mathrm{~S} 1$ & $\mathrm{~S} 1$ & $\mathrm{~S} 1$ \\
\hline Topography (t) & Slope $(\%)$ & $0-15$ & $1-3$ & $1-2$ & $1-3$ & $\mathrm{~S} 1$ & $\mathrm{~S} 1$ & $\mathrm{~S}$ \\
\hline \multirow[t]{3}{*}{ Soil physical property(s) } & Soil texture & SL, SCL, L & SCL & SL to SCL & $\mathrm{SC}$ & $\mathrm{S} 1$ & $\mathrm{~S} 1$ & $\mathrm{~S} 2$ \\
\hline & Effective depth $(\mathrm{cm})$ & $>50 \mathrm{~cm}$ & $>200 \mathrm{~cm}$ & $>167 \mathrm{~cm}$ & $>170 \mathrm{~cm}$ & $\mathrm{~S} 1$ & $\mathrm{~S} 1$ & $\mathrm{~S} 1$ \\
\hline & Soil drainage & $\begin{array}{l}\text { Moderate to well } \\
\text { drained }\end{array}$ & $\begin{array}{l}\text { Well } \\
\text { drained }\end{array}$ & $\begin{array}{l}\text { Moderate to well } \\
\text { drained }\end{array}$ & Well drained & $\mathrm{S} 1$ & $\mathrm{~S} 1$ & $\mathrm{~S} 1$ \\
\hline \multirow[t]{2}{*}{ Soil toxicity (n) } & $\mathrm{EC}\left(\mathrm{dS} \mathrm{m} \mathrm{m}^{-1}\right)$ & $2-4$ & $0.01-0.02$ & $0.01-0.05$ & $0.01-0.03$ & $\mathrm{~S} 1$ & $\mathrm{~S} 1$ & $\mathrm{~S} 1$ \\
\hline & $\operatorname{ESP}(\%)$ & $<6$ & $0.21-0.78$ & $0.05-3.08$ & $0.43-0.65$ & $\mathrm{~S} 1$ & $\mathrm{~S} 1$ & $\mathrm{~S} 1$ \\
\hline Soil fertility (f) & Soil $\mathrm{pH}_{\text {water }}$ & $4.5-7.0$ & $5.0-5.46$ & $5.08-5.82$ & $5.15-5.57$ & $\mathrm{~S} 1$ & $\mathrm{~S} 1$ & $\mathrm{~S} 1$ \\
\hline
\end{tabular}




\begin{tabular}{|c|c|c|c|c|c|c|c|c|}
\hline \multirow{2}{*}{ Land quality } & \multirow{2}{*}{ Diagnostic factor } & \multirow{2}{*}{ Required range } & \multicolumn{3}{|c|}{ Actual field range } & \multicolumn{3}{|l|}{ Rating } \\
\hline & & & MARU-P1 & MISSE-P1 & BIHA-P1 & MARU-P1 & MISSE-P1 & BIHA-P1 \\
\hline & OC (\%) & $2-4$ & $0.90-3.20$ & $0.50-1.20$ & $0.70-1.70$ & S1 & S3 & S2 \\
\hline & TN (\%) & $0.14-0.2$ & $0.07-0.44$ & $0.01-0.10$ & $0.04-0.14$ & $\mathrm{~S} 1$ & S2 & S1 \\
\hline & Avail. $\mathrm{P}\left(\mathrm{mg} \mathrm{kg}^{-1}\right)$ & $10-14$ & $3.03-6.17$ & $6.07-41.98$ & $1.48-6.32$ & S2 & S1 & S2 \\
\hline & $\mathrm{K}\left(\mathrm{cmol}(+) \mathrm{kg}^{-1}\right)$ & $0.2-0.4$ & $0.12-0.18$ & $0.19-0.53$ & $0.07-0.11$ & S2 & S1 & S3 \\
\hline & $\mathrm{Ca}\left(\mathrm{cmol}(+) \mathrm{kg}^{-1}\right)$ & $1.0-5.0$ & $0.56-1.78$ & $1.78-4.40$ & $2.70-5.80$ & S1 & S1 & S1 \\
\hline & $\operatorname{Mg}\left(\operatorname{cmol}(+) \mathrm{kg}^{-1}\right)$ & $0.4-1.0$ & $0.19-0.56$ & $1.00-2.10$ & $0.77-2.09$ & S1 & S1 & S1 \\
\hline & $\mathrm{Cu}\left(\mathrm{mg} \mathrm{kg}^{-1}\right)$ & $0.3-1.0$ & $1.14-3.10$ & $0.49-2.65$ & $0.29-3.54$ & S1 & $\mathrm{S} 1$ & S1 \\
\hline & $\operatorname{Mn}\left(\mathrm{mg} \mathrm{kg}^{-1}\right)$ & $10.0-100.0$ & $4.01-12.9$ & $1.48-74.83$ & $1.59-24.19$ & S1 & S1 & S1 \\
\hline & $\mathrm{Fe}\left(\mathrm{mg} \mathrm{kg}^{-1}\right)$ & $10.0-100.0$ & $65-100.01$ & $39.25-98.21$ & $12.76-45.67$ & S1 & S1 & S1 \\
\hline & $\mathrm{Zn}\left(\mathrm{mg} \mathrm{kg}^{-1}\right)$ & $1.0-5.0$ & $0.22-1.39$ & $0.93-6.61$ & $0.56-1.28$ & $\mathrm{~S} 1$ & $\mathrm{~S} 1$ & $\mathrm{~S} 1$ \\
\hline Overall rating & & & & & & S2f & S3f & S3f \\
\hline
\end{tabular}

MARU-P1 = Maruku profile 1; MISSE-P1 = Missenyi profile 1; BIHA-P1 = Biharamulo profile $1 ; \mathrm{Zn}=\mathrm{zinc} ; \mathrm{Fe}=$ iron; $\mathrm{Mn}=$ manganese; $\mathrm{Cu}=\mathrm{copper}$; Ca = calcium; $\mathrm{Mg}=$ magnesium; $\mathrm{K}=$ potassium; $\mathrm{OC}=$ organic carbon; $\mathrm{TN}=$ total nitrogen; $\mathrm{EC}=$ electrical conductivity

Note: The small values of soil toxicity and soil fertility diagnostic factors are from subsoils ranging from $75-200 \mathrm{~cm}$ from the surface and the high values are from the topsoils ranging from $0-75 \mathrm{~cm}$ of the studied pedons

\section{Conclusions and Recommendations}

\subsection{Conclusions}

Pedons MARU-P1 and BIHA-P1 have similar morphological properties, which are different from those of pedon MISSE-P1. Moreover, all studied pedons differ in terms of their physical and chemical properties, implying differences in terms of their use and management. This emphasizes the need to characterize soils before decisions on land use are made. Climatic conditions of the study areas are characterized as semi-humid with Udic soil moisture regime and Isohyperthermic soil temperature regime, both of which are favourable for crop production.

Due to its finer soil texture, pedon MARU-P1 exhibits more favourable moisture retention characteristics followed by pedon BIHA-P1 and lastly pedon MISSE-P1. The ESP levels indicate that the studied soils are non-sodic and pose no limitation to crop production. In terms of nutrient balance, all studied pedons have favourable $\mathrm{Ca}: \mathrm{Mg}$ ratios indicating the balance of $\mathrm{Ca}$ and $\mathrm{Mg}$, whereas the Ca:TEB ratios are unfavourable indicating imbalance of $\mathrm{Ca}$ and other exchangeable bases like $\mathrm{K}$ and Na for plant uptake. Micronutrient levels of the studied pedons range from low to high with high levels of $\mathrm{Zn}, \mathrm{Cu}$ and $\mathrm{Mn}$ in topsoils. The most abundant oxide in the studied pedons is $\mathrm{SiO}_{2}$ followed by $\mathrm{Al}_{2} \mathrm{O}_{3}$ and $\mathrm{Fe}_{2} \mathrm{O}_{3}$ indicating that quartzite and shale are the dominant parent rocks in the study areas. In terms of weathering indices, pedon MARU-P1 is more highly weathered followed by BIHA-P1 and lastly MISSE-P1. On the basis of $\mathrm{pH}, \mathrm{SOC}, \mathrm{TN}$, available $\mathrm{P}, \mathrm{CEC}$ and $\mathrm{BS}$, the studied pedons are generally rated as having low to medium soil fertility.

Pedons MARU-P1 and BIHA-P1 classified both as "Typic Kandiudults" according to USDA Soil Taxonomy and as "Haplic Ferralic Acrisols" and "Chromic Ferralic Acrisols" respectively, according to FAO World Reference Base for Soil Resources. Pedon MISSE-P1 classified as "Typic Endoaquolls" according to USDA Soil Taxonomy and as "Fluvic Gleyic Phaeozems" according to FAO World Reference Base for Soil Resources. Pedons MISSE-P1 and BIHA-P1 were both evaluated as marginally suitable while pedon MARU-P1 was evaluated as moderately suitable for cassava production due to soil fertility problems caused by very low organic carbon in pedon MISSE-P1, very low exchangeable $\mathrm{K}$ in pedon BIHA-P1 and low available $\mathrm{P}$ and exchangeable $\mathrm{K}$ in pedon MARU-P1.

\subsection{Recommendations}

Soil fertility management strategies need to be deployed for optimum cassava yields in the study areas. These include:

1) application of P-containing fertilizers such as triple superphosphate (TSP) and K-containing fertilizers such as muriate of potash (MOP) at the recommended rates for the area represented by pedon MARU-P1.

2) application of $\mathrm{N}$-containing fertilizers such as calcium ammonium nitrate (CAN), farmyard manure and/or compost and incorporation of crop residues into the soil for improving the current level of $\mathrm{OC}$ and $\mathrm{N}$ for the area represented by pedon MISSE-P1.

3) application of $\mathrm{K}$ and P-containing fertilizers, farmyard manure and/or compost and incorporation of crop residues into the soil for improving the current levels of $\mathrm{K}$ and $\mathrm{OC}$ for the area represented by pedon BIHA-P1.

Other soil fertility management strategies should include crop rotation, fallowing, intercropping, use of leguminous and cover crops and retention of crop residues in the field after crop harvesting to allow their decomposition within the field.

In view of the fact that topsoils of the studied pedons have high levels of zinc and copper, we recommend sustainable management of $\mathrm{Zn}$ and $\mathrm{Cu}$ such as limited use of $\mathrm{Zn}$ and $\mathrm{Cu}$ containing fungicide.

Given that this study presents information on pedological characteristics and suitability of the study areas for cassava production, we recommend further pedological characterization and suitability assessment for other major crops grown in the study areas and other districts of Kagera Region to establish specific recommendations on land use and management for sustainable crop production in the region.

\section{Acknowledgements}

We thank Alliance for Green Revolution in Africa (AGRA) 
through Advancing Soil Health in Africa Project at Sokoine University of Agriculture (SUA), Morogoro, Tanzania for the financial support that enable the completion of this research study.

\section{References}

[1] Msanya, B. M., Kaaya, A. K., Araki, S., Otsuka, H. and Nyadzi, G. I. (2003). Pedological characteristics, general fertility and classification of some benchmark soils of Morogoro District, Tanzania. African Journal of Science and Technology Science and Engineering Series, 4 (2): 101-112.

[2] Karuma, A. N., Gachene, K., Charles, K., Msanya, B. M., Mtakwa, P. W., Amuri, N. and Gicheru, P. T. (2015). Soil morphology, physico-chemical properties and classification of typical soils of Mwala District, Kenya. International Journal of Plant and Soil Science, 4 (2): 156-170.

[3] Muya, E. M., Obanyi, S., Ngutu, M., Sijali, I. V., Okoti, M., Maingi, P. M. and Bulle, H. (2011). The physical and chemical characteristics of soils of Northern Kenya Arid lands: Opportunity for sustainable agricultural production. Journal of Soil Science and Environmental Management, 2 (1): 1-8.

[4] Robert, P. (1993). Characterization of soil conditions at the field level for soil specific management. Geoderma, 60 (1-4): 57-72.

[5] Msanya, B. M., Kimaro, D. N., Kimbi, G G., Kileo, E. P. and Mbogoni, J. D. J. (2001). Land resources inventory and suitability assessment for the major land use types in Morogoro Urban District, Tanzania: Soils and Land Resources of Morogoro Rural and Urban Districts, Volume 4. Department of Soil Science, SUA, Morogoro, Tanzania. pp. 166.

[6] Kalala, A. M., Msanya, B. M., Amuri, N. A. and Semoka, J. M. (2017). Pedological characterization of some typical alluvial soils of Kilombero District, Tanzania. American Journal of Agriculture and Forestry, 5 (1): 1-11.

[7] Msanya, B. M., Mwasyika, T. A., Amuri, N., Semu, E. and Mhoro, L. (2018). Pedological characterization of typical soils of Dodoma Capital City District, Tanzania: soil morphology, physico-chemical properties, classification and soil fertility trends. Annals of Advanced Agricultural Sciences, 2 (4): 5973.

[8] Msanya, B. M., Munishi, J., Amuri, N., Semu, E., Mhoro, L. and Malley, Z. (2016). Morphology, genesis, physicochemical properties, classification and potential of soils derived from volcanic parent materials in selected Districts of Mbeya Region, Tanzania. International Journal of Plant and Soil Science, 10 (4): 1-19.

[9] Tenga, J. J., Msanya, B. M., Semoka, J. M., Semu, E. and Mwango, S. B. (2018). Pedological characterization and classification of some typical soils in three agro-ecological settings of South-Eastern Tanzania. International Journal of Scientific and Engineering Research, 9 (2): 692-702.

[10] Onyekanne, C. F. and Nnaji, G. U. (2012). Characterization and classification of soils of Ideato North local government area. Nigerian Journal of Soil Science, 22 (1): 11-17.

[11] Lufega, S. M. and Msanya, B. M. (2017). Pedological characterization and soil classification of selected soil units of
Morogoro District, Tanzania. International Journal of Plant and Soil Science, 16 (1): 1-12.

[12] Chekol, W. and Mnalku, A. (2012). Selected physical and chemical characteristics of soils of the middle awash irrigated farm lands, Ethiopia. Ethiopian Journal of Agricultural Sciences, 22 (1): 127-142.

[13] Adhanom, D. and Toshome, T. (2016). Characterization and classification of soils of Aba-Midan sub watershed in Bambasi Wereda, West Ethiopia. International Journal of Scientific and Research Publications, 6 (6): 390-399.

[14] Rajeshwar, M. and Mani, S. (2015). Genesis, classification and evaluation of cotton growing soils in semi arid tropics of Tamil Nadu. Asian Journal of Soil Science, 10 (1): 130-141.

[15] Ukut, A. N., Akpan, U. S. and Udoh, B. T. (2014). Characterization and classification of soils in steep sided hills and sharp-crested ridges of Akwa Ibom State, Nigeria. Net Journal of Agricultural Science, 2 (2): 50-57.

[16] Kebeney, S. J., Msanya, B. M., Ng'etich, W. K., Semoka, J. M. and Serrem, C. K. (2014). Pedological characterization of some typical soils of Busia County, Western Kenya: Soil morphology, physico-chemical properties, classification and fertility trends. International Journal of Plant and Soil Science, 4 (1): $29-44$.

[17] Sehgal, J. L. (1991). Soil-site suitability evaluation for cotton. Agropedology, 1: 49-63.

[18] Ande, O. T. (2011). Soil suitability evaluation and management for cassava production in the derived Savanna Area of Southwestern Nigeria. International Journal of Soil Science, 6 (2): 142-149.

[19] Bandyopadhyay, S., Jaiswal, R. K., Hegde, V. S. and Jayaraman, V. (2009). Assessment of land suitability potentials for agriculture using a remote sensing and GIS based approach. International Journal of Remote Sensing, 30 (4): 879-895.

[20] Narayanaswamy, Y. A., Inayathulla, M., Thabrez, M. and Shashishankar, A. (2017). Land suitability evaluation of soils for crop production. Internatinal Journal Innovative Research Science Enginering Technology, 6 (9): 18187-18196.

[21] Denis, M. K. A., Patil, P. L., Gali, S. K. and Quee, D. D. (2016). Soil suitability assessment for sustainable production of vegetable crops in Northern semi-arid region of India. International Journal of Agricultural Policy and Research, 4 (3): 52-61.

[22] Mbaga, H. R., Msanya, B. M. and Mrema, J. P. (2017). Pedological characterization of typical soil of Dakawa Irrigation Scheme, Mvomero District, Morogoro Region, Tanzania. International Journal of Current Research in Biosciences and Plant Biology, 4 (6): 77-86.

[23] Msanya, B. M. and Magoggo, J. P. (1993). Review of Soil Surveys (Soil Resource Inventories) inTanzania. Ecology and Development Programme, 804-2144.

[24] Kilasara, M., Magoggo, J. P. and Msanya, B. M. (1994). Land resource management in Tanzania In: Proceedings of the Faculty of Agriculture Research Workshop held at the Institute of Continuing Education, Sokoine University of Agriculture, (Edited by A. J. P. Tarimo, D. F. Rutatora and A. Z. Mattee), 21-23 March, 1994. Morogoro, Tanzania. 
[25] Shelukindo, H. B., Msanya, B. M., Semu, E., Mwango, S. B., Munishi, P. K. T. and Singh, B. R. (2013). Characterization of some soils of the Miombo Woodlands Ecosystem of Kitonga Forest Reserve, Iringa, Tanzania: Physico-chemical properties and classification. In: Joint proceedings of the $27^{\text {th }}$ Soil Science Society of East Africa and the $6^{\text {th }}$ African Soil Science Society, October 2013. Nakuru, Kenya.

[26] Kimaro, D. N., Msanya, B. M., Meliyo, J., Hieronimo, P., Mwango, S., Kihupi, N. I., Gulinck, H. and Deckers, J. A. (2014). Anthropogenic soils and land use patterns in relation to small mammal and flea abundance in plague endemic area of Western Usambara Mountains, Tanzania. Tanzania Journal of Health Research, 16 (3): 1-12.

[27] Mfaume, D. P., Msanya, B. M. and Msaky, J. J. (2019). Pedological Characterization and Fertility Assessment of Mbimba Substation Soils Under Coffee Production in Mbozi District, Tanzania. International Journal of Advances in Scientific Research and Engineering, 5 (10): 22 1-236.

[28] United Republic of Tanzania (URT) (2019). Kagera Region Investment Guide-2019. Kagera Regional Commissioner Office, Kagera, Tanzania. 92 pp.

[29] Oosterom, A. P., Ngailo, J. A., Kileo, R. O., Mbogoni, J. D. J., Msangi, A. S., Andriesse, W. and van Kekem, A. J. (1999). Land Resources of Biharamulo District, Kagera region, Tanzania, International Activities Report 75. Winand Staring Centre, Wageningen (The Netherlands). 160 pp.

[30] Baijukya, F. P. and Folmer, E. C. R. (1999). Agro-Ecological Zonation of the Kagera region. In: Planning the Future: Past, Present and Future Perspectives of Land Use in Kagera Region. (Edited by Folmer, E. C. R. Schouten, C. and Baijukya, F. P.), Bukoba, Kagera, Tanzania. pp. 28-39.

[31] United Republic of Tanzania (URT) (2012). National Sample Census of Agriculture 2007/2008 Regional Report-Kagera Region, Volume V. National Bureau of Statistics, Dar es Salaam, Tanzania. $315 \mathrm{pp}$.

[32] Food Agricultural Organization (FAO) (2006). Guidelines for Soil Description. 4th edition. Food and Agriculture Organization of the United Nations, Rome, Italy. 66 pp.

[33] Munsell Colour Company (MCC) (2000). Munsell Soil Colour Charts. 2000 Reviewed Washable Edition. Gretag Macbeth, Windsor, New York. 10 pp.

[34] Bradford, J. M. (1986). Penetrability. In:. Methods of Soil Analysis: Part 1 Physical and Mineralogical Methods. (Edited by Klute A). American Society of Agronomy, Soil Science Society of America, Madison, Wisconsin, pp. 463478.

[35] Taylor, H. M., Roberson, G. M. and Parker Jr, J. J. (1966). Soil strength-root penetration relations for medium-to coarsetextured soil materials. Soil science 102 (1): 18-22.

[36] Pabin, J., Lipiec, J., Włodek, S., Biskupski, A. and Kaus, A., (1998). Critical soil bulk density and strength for pea seedling root growth as related to other soil factors. Soil and Tillage Research, 46 (3-4): 203-208.

[37] Hazelton, P. and Murphy, B. (2016). Interpreting Soil Test Research: What do all the number mean? $3^{\text {rd }}$ Edition. Commonwealth Scientific and Industrial Research Organisation (CSIRO) Publishing. Clayton South, Australia. $186 \mathrm{pp}$.
[38] Soil Science Division Staff (2017). Soil Survey Manual. United State Department of Agriculture, United State of America. 603 pp.

[39] Day, P. R (1965). Particle fractionation and particle size analysis. In: Methods of Soil Analysis, Part 1. (Edited by Black, C. A., Evans, D. D., White, J. L., Ensminger, L. E. and Clark, F. E.), American Society of Agronomy, Madison, Wisconsin. pp. 545-566.

[40] Moberg, J. P. (2001). Soil Analysis Manual (revised edition). The Royal Veterinary and Agricultural University, Chemistry Department, Copenhagen, Denmark. 137 pp.

[41] Soil Survey Staff (2014). Keys to Soil Taxonomy. $12^{\text {th }}$ Edition. Natural Resources Conservation Service, United States Department of Agriculture (USDA) Handbook, Washington DC. 372 pp.

[42] National Soil Service (NSS) (1990). Laboratory procedures for routine analysis, 3rd edition. Agricultural Research Institute, Mlingano Tanga, Tanzania. $212 \mathrm{pp}$.

[43] Saka, A. R. and Haque, I. (1993). Methods of analysis for selected soil physical properties. Soil Science Fact Sheet No. 2. Department of Agricultural Research, Chitedze Agricultural Research Station, Lilongwe, Malawi. 74 pp.

[44] Klute, A. (1986). Water retention. In: Methods of Soil Analysis, Part 1, and Agronomy Monograph No. 9. (Edited by Klute, A.). American Society of Agronomy and Soil Science Society of America, Madison, Wisconsin. pp. 635-662.

[45] Okalebo, J. R., Gathua, K. W and Woomer, P. L. (2002). Laboratory methods of soil and plant analysis: A working manual. $2^{\text {nd }}$ edition. 128. TSBF-CIAT and SACRED Africa, Nairobi. 127 pp.

[46] Nelson, D. W. and Sommers L. E. (1986). Total carbon, organic carbon, and organic matter. In: Methods of Soil Analysis II: Chemical and Microbiological properties. Second Edition. (Edited by. Page, A. L. Miller, R. H. Keeney, D. R. Baker, D. E. Roscoe E. Ellis, J. and Rhodes, J. D). Madison, Wisconsin, USA. pp. 539-581

[47] Duursma, E. K. and Dawson, R. (eds) (1981). Marine organic chemistry: Evolution, composition, interactions and chemistry of organic matter in seawater. Elsevier. 521 pp.

[48] Bremner, J. M. and Mulvaney, C. S. (1982). Total nitrogen. In: Methods of Soil Analysis, Part 2. (Edited by Black et al., 1981) Agronomy Monograph 9, American Society of Agronomy, Madison, Wisconsin, USA. pp. 1149-1170.

[49] Bray, R. H. and Kurtz, L. T. (1945). Determination of total, organic and available forms of phosphorus in soils. Soil Science, 59: 39-45.

[50] Thomas, G. W., (1986). Exchangeable cations. In: Methods of Soil Analysis II: Chemical and Microbiological Properties. Second Edition. (Edited by, Page, A. L. Miller, R. H. Keeney, D. R. Baker, D. E. Roscoe E. Ellis, J. and Rhodes, J. D.). Madison, Wisconsin, USA. pp. 403-430.

[51] Chapman, H. D. (1965). Cation exchange capacity. In: Methods of Soil Analysis. (Edited by Black C. A). American Institute of Agronomy, 9: 891-901.

[52] Lindsay W. L. and Norvell W. A. (1978). Development of a DTPA soil test for zinc, iron, manganese and copper. Soil Science Society of America Journal, 42: 421-428. 
[53] Landon, J. R. (1991). Booker Tropical Soil Manual. A handbook for soil survey and agricultural land evaluation in the tropics and subtropics, Longman Scientific and Technical Publishers, Essex. 474 pp.

[54] Takahashi, G. (2015). Sample preparation for X-ray fluorescence analysis. Rigaku Journal, 31: 26-30.

[55] Mobius, J., Lahajnar, N. and Emeis, K. C. (2010). Diagenetic control of nitrogen isotope ratios in Holocene sapropels and recent sediments from the Eastern Mediterranean Sea. Biogeosciences, 7: 3901-3914.

[56] IUSS Working Group WRB. (2015). World Reference Base for Soil Resources 2014, update 2015. International soil classification system for naming soils and creating legends for soil maps. World Soil Resources Reports No. 106. FAO, Rome, Italy. 203 pp.

[57] Food Agricultural Organization (FAO) (1976). A framework for land evaluation. Soils Bulletin 3, Rome, Italy. 72 pp.

[58] Sys, C., Van Ranst, E. and Debavye, J. (1991). Land evaluation, Part 2. Methods of land evaluation. Agriculture Publication. No. 7, Belgium. 247 pp.

[59] Howeler, R. H. (2002). Cassava Mineral Nutrition and Fertilization. In: Cassava: Biology, Production and Utilization. Hillocks, R. J., Thresh, M. J. and Bellotti, A. C. (Eds.). CABI Publishing, Wallingford, Oxon, United Kingdom. pp. 115-147.

[60] Howeler, R. H. (ed) (2011). The Cassava Handbook. A Reference Manual on the Asian Regional Cassava Training Course, held in Thailand. Centro Internacional de Agricultura Tropical (CIAT), Thailand. 801pp.

[61] Abua, M. A. (2015). Suitability assessment of soils for cassava production in the coastal and hinterland areas of southern Cross River state, Nigeria. Journal of Science and Environmental Management, 6 (5): 108-115.

[62] Baijukya, F. P. (2004). Adapting to change in banana-based farming systems of Northwest Tanzania: The potential role of herbaceous legume. Thesis for the ward a PhD Degree at the Wageningen University. Wageningen. The Netherland. 192 pp.

[63] Touber, L. and Kanani, J. R. (1994). Landforms and soils of Bukoba District. Bukoba District Rural Development Programme. NEDWORC, Networking in Development, The Netherland. 145 pp.

[64] Khan, Z. H., Hussain, M. S. and Ottner, F. (2012). Morphogenesis of Three Surface-Water Gley Soils from the Meghna Floodplain of Bangladesh. Dhaka University Journal of Biological Science, 21 (2): 17 - 27.

[65] Obasi, S. N., Onweremadu, E. U., Egbuche, C. T. and Iwuanyanwu, U. P. (2015). Characterization and Classification of Selected Rice Soils of Tropical Rainforest Region, Southeastern Nigeria. Agriculture, Forestry and Fisheries, 4 (3): 46-50.

[66] Brady, N. C. and Weil, R. R. (2017). The nature and properties of soil. $15^{\text {th }}$ Edition. Pearson Education. Essex, England. 1104 pp.

[67] Lal, R and Shukla, M. K. (eds) (2005). Principles of Soil Physics. Marcel Dekker, Incorporation. New York. 716 pp.

[68] Saglam, M. and Dengiz, O. (2014). Distribution and evaluation of soil fertility based on geostatistical approach in
Bafra Deltaic Plain. Turkish Journal of Agricultural Research, 1 (2): 186-195.

[69] Pal, D. K., Srivastava, P. and Bhattacharyya, T. (2003). Clay illuviation in calcareous soils of the semiarid part of the IndoGangetic Plains, India. Geoderma, 115 (3-4): 177-192.

[70] Akpan-Idiok, A. U. and Ogbaji, P. O. (2013). Characterization and Classification of Onwu River Floodplain Soils in Cross River State, Nigeria. International Journal of Agricultural Research, 8: 107-122.

[71] Moraes, M. T. D., Silva, V. R. D., Zwirtes, A. L. and Carlesso, R. (2014). Use of penetrometers in agriculture: a review. Engenharia Agrícola, 34 (1): 179-193.

[72] Uwingabire, S. (2016). Pedological characterization of soils developed on gneissic-granites in Congo Nile watershed divide and central Plateau zones of Rwanda. Thesis for award of $\mathrm{PhD}$ Degree at the Sokoine University of Agriculture, Morogoro, Tanzania. $102 \mathrm{pp}$.

[73] Costantini, E. A., Angelone, M. and Damiani, D. (2002). Physical, geochemical and mineralogical indicators of aging in Quaternary soils of Central Italy. In: $17^{\text {th }}$ World Congress of Soil Science, Transactions. International Union of Soil Sciences, 599: 1-9.

[74] Bwana, T. N. (2019). Environmental performance of smallholder organic and conventional cotton production systems in Meatu, Tanzania. Thesis for award of PhD Degree at the Sokoine University of Agriculture, Morogoro, Tanzania. 190pp.

[75] Munishi, J. A. (2012). Pedological characterization of soils and assessment of their agricultural potential in selected Districts of Mbeya Region, Tanzania. Thesis for award of MSc Degree at the Sokoine University of Agriculture, Morogoro, Tanzania. $136 \mathrm{pp}$.

[76] Uwitonze, P., Msanya, B. M., Mtakwa, P. W., Uwingabire, S., Sirikare, S. (2016). Pedological characterization of soils developed from volcanic parent materials of Northern Province of Rwanda. Agriculture, Forestry and Fishing, 5 (6): 225-236.

[77] EuroConsult (1989). Agricultural Compendium for Rural Development in the Tropics and Subtropics, $3^{\text {rd }}$ edition, Elsevier Science Publishers. Amsterdam. 740 pp.

[78] Baize, D. (1993). Soil Science Analyses. A Guide to Current Use. John Wiley \& Sons Ltd. West Sussex. 192pp.

[79] Horneck, D. D., Sullivan, D. M., Owen, J. S. and Hart, J. M. (2011). Soil Test Interpretation Guide. Extension services, Oregon State University. 12 pp.

[80] Ndakidemi P. A. and Semoka J. M. R. (2006). Soil Fertility Survey in Western Usambara Mountains, Northern Tanzania. Pedosphere 16 (2): 237-244.

[81] Sanginga, N. and Woomer, P. L. (eds.) (2009). Integrated Soil Fertility Management in Africa: Principles, Practices and Development Process. Tropical Soil Biology and Fertility Institute of the International Centre for Tropical Agriculture. Nairobi, Kenya. 263 pp.

[82] Ge, S., Xu, H., Ji, M. and Jiang, Y. (2013). Characteristics of Soil Organic Carbon, Total Nitrogen, and $\mathrm{C} / \mathrm{N}$ Ratio in Chinese Apple Orchards. Open Journal of Soil Science, 3: 213-217. 
[83] Tabi, F. O., Ngobesing, E. S. C., Yinda, G. S., Boukong, A., Omoko, M., Bitondo, D. and Mvondo Ze, A. D. (2013). Soil fertility capability classification (FCC) for rice production in Cameroon lowlands. African Journal of Agricultural Research, 8 (119): 1650-1665.

[84] Barker, A. V. and Pilbeam D. J. (2007). Handbook of plant nutrition. Taylor and Francis, London, New York. 662pp.

[85] Wiyantoko, B., and Rahmah, N. (2017). Measurement of cation exchange capacity (CEC) on natural zeolite by percolation method. In AIP Conference Proceedings, Vol. 1911, 020021, No. 1, AIP Publishing LLC. Doi: $10.1063 / 1.5016014$.

[86] Van Wambeke, A. (1962). Criteria for classifying tropical soils by age. Journal of soil Science, 13 (1): 124-132.

[87] Edem, S. O. and Ndaeyo, N. U. (2009). Fertility status and management implications of wetland soils for sustainable crop production in Akwa Ibom State, Nigeria. Environment development and sustainability, 11 (2): 393-406.

[88] Yilmaz, K., Çelik, I., Kapur, S. and Ryan, J. (2005). Clay minerals, $\mathrm{Ca} / \mathrm{Mg}$ ratio and $\mathrm{Fe}-\mathrm{Al}$-oxides in relation to structural stability, hydraulic conductivity and soil erosion in southeastern Turkey. Turkish Journal of Agriculture and Forestry, 29 (1): 29-37.

[89] Sillanpää, M. (1982). Micronutrients and the nutrient status of soils: A global study, FAO soils bulletin no 48, FAO. Rome, Italy. pp. 17-97.

[90] Esu, I. E (1991). Detailed soil survey of National Horticultural Research Institute (NIHORT) Farm at Bunkure, Kano State, Nigeria. Institute for Agricultural Research, Ahmad Bello University, Zaria, Nigeria. 72 pp.

[91] Deb, D. L. and Sakal, R. (2002). Micronutrients. In Indian Society of Soil Science. Indian Research Institute, New Delhi. pp. 391-403.

[92] Motsara, M. R., and Roy, R. N. (2008). Guide to laboratory establishment for plant nutrient analysis, Vol. 19. Rome: Food and Agriculture Organization of the United Nations. 219 pp.

[93] Mustapha, S., Mamman, H. K, Abdulhamid, N. A. (2010). Status and distribution of extractable micronutrients in Haplustults in Yamaltu-Deba Local Government Area, Gombe State, Nigeria. Journal of Soil Science and Environmental Management, 1 (8): 200-204.

[94] Bassirani, N. Abolhassani, M. and Galavi, M. (2011). Distribution of available micronutrients as related to the soil characteristics of Hissar; Haryana, India. Africa Journal of Agricultural Research, 6 (18): 4239-4242.
[95] Dos-Santos, G. C. G., Valladares, G. S., Abreu, C. A., de Camargo, O. A., and Grego, C. R. (2013). Assessment of copper and zinc in soils of a vineyard region in the state of São Paulo, Brazil. In Applied and Environmental Soil Science. Hindawi Publishing Corporation, Sao Paulo, Brazil. 10 pp.

[96] Mulima, I. M., Shafiu, M., Ismaila, M., and Benisheikh, K. M. (2015). Status and Distribution of Some Available Micronutrients in Sudan and Sahel Savanna Agro-Ecological Zones of Yobe State, Nigeria. Journal of Environmental Issues and Agriculture in Developing Countries, 7 (1): 18-29.

[97] Oyinlola, E. Y. and Chude, V. O. (2010). Status of available micronutrients of the basement complex rock derived Alfisols in Northern Nigeria Savanna. Tropical and subtropical Agroecosystems, 12 (2): 229-237.

[98] Towett, E. K., Shepherd, K. D., Tondoh, J. E., Winowiecki, L. A., Lulseged, T., Nyambura, M., Sila, A., Vågen, T. G. and Cadisch, G., (2015). Total elemental composition of soils in Sub-Saharan Africa and relationship with soil forming factors. Geoderma Regional, 5: 157-168.

[99] Rawlins, B. G., McGrath, S. P., Scheib, A. J., Breward, N. Cave, M., Lister, T. R., Ingham, M., Gowing, C. and Carter, S. (2012). The Advanced Soil Geochemical Atlas of England and Wales. British Geological Survey, 1472-148.

[100] Baba, M., Hennie, F. W., Soehady, E. and Sanudin, T. (2008). Geochemical characterization of volcanic soils from Tawau, abah. Geological Society of Malaysia Bulletin, 54: 33-36.

[101] Acosta, J. A., Martinez, S., Faz, A. and Arocena, J. (2011). Accumulations of major and trace elements in particle size fractions of soils on eight different parent materials. Geoderma, 161: 30-42.

[102] Ceryan, S., Ceryan N. and Aydın, A. (2005). Determination of weathering in engineering time using interaction matrices. In: Proceedings. of $1^{\text {st }}$ International Symposium on Travertine, September 21-25, Pamukkale University, Denizli, Turkey. pp. 297-304.

[103] Ceryan, S. (2012). Weathering indices for assessment of weathering effect and classification of weathered rocks: a case study from North-East Turkey. Earth Sciences, 19-44.

[104] Yanai J., Okada, T. and Yamada, H. (2012). Elemental composition of agricultural soils in Japan in relation to soil type, land use and region. Soil Science and Plant, 58: 1-10.

[105] Nesbitt, H. W. and Young, G. M. (1982). Early Proterozoic climates and plate motions inferred from major element chemistry of Lutites. Nature, 299: 715-717.

[106] Cocks, J. H. (1985) Cassava: New Potential for a Neglected Crop. West view, Boulder, USA. 191 pp. 